\title{
Reverse Assimilation? Immigrants in the Canadian Labour Market During the Great Depression*
}

\author{
Kris Inwood ${ }^{\mathrm{a}}$, Chris Minns ${ }^{\mathrm{b}}$, and Fraser Summerfield ${ }^{\mathrm{c}}$
}

${ }^{a}$ Department of Economics and Department of History, University of Guelph, kinwood@uoguelph.ca

${ }^{\mathrm{b}}$ Department of Economic History, London School of Economics and Political Science,c.minns@lse.ac.uk

${ }^{\mathrm{c}}$ Department of Economics, University of Aberdeen, fsummerfield@abdn.ac.uk

February 2016

\footnotetext{
* We thank Javier Torres and participants at the 2013 British Association for Canadian Studies, 2013 European Historical Economics Society, Essex FRESH, the 2013 Canadian Economics Association Meetings, the Cliometrics session at the 2014 ASSA, three anonymous referees and seminar participants at the University of Sussex and the University of York for their comments.
} 
Abstract: This paper uses Canadian Census data from 1911 to 1931 to trace the labour market assimilation of immigrants up to the onset of the Great Depression. We find that substantial earnings convergence between 1911 and 1921 was reversed between 1921 and 1931, with immigrants from Continental Europe experiencing a sharp decline in earnings relative to the native-born. The effect of Depression labour market conditions was particularly pronounced among older immigrants with long tenures in Canada.

Keywords: Canada; Immigrants; Assimilation; Earnings; Wages; Early $20^{\text {th }}$ Century; Great Depression; Labour Markets

JEL Codes: J15; J31; J61; N32 


\section{Introduction}

The recent global economic crisis has prompted renewed interest in the implication of business cycles for immigrant labour market outcomes (Barrett and Kelly 2011; Orrenius and Zavodny 2010). Several authors have found mixed evidence for an immigrant "scarring” effect of recessions (Åslund and Rooth 2007; Bloom, Grenier, and Gunderson 1995; Chiswick and Miller 2002), while others show faster assimilation in earnings and employment among those arriving during recessions (MacDonald and Worswick 1999; Chiswick et. al. 1997). Recent shocks, however, are dwarfed by the disturbances of the late 1920s and early 1930s.

The Great Depression is the largest, deepest shock to hit North American labour markets. Numerous studies have explored the impact of the Depression on the pay and employment of different demographic groups, ${ }^{1}$ but most comparisons omit the large numbers of foreign-born. While it is established that unemployment was higher among immigrants than the native-born (Green and MacKinnon 1988; Gemery 1993), little else is known about the foreign-born experience of the Depression. There are several reasons to anticipate that immigrants were especially vulnerable. While unemployment rose substantially in all walks of life, industrial workers suffered most, particularly in urban semi-skilled and unskilled jobs held disproportionately by immigrants. Even in white-collar and clerical employment Depression employment conditions could have magnified any differences in job search costs between immigrants and the native-born. $^{2}$

More generally, if observable ethnic identity mattered in labour markets before the Second World War, then the scale of the Depression shock may modify our understanding of immigrant labour market assimilation at the end of the so-called First Great Migration. Historical studies of mass migration have documented differences in economic status among immigrant origin groups, and changes in cohort “quality” within immigrant origin groups (Douglas 1919; Hatton 2000; Minns 2000; Abramitzky, Boustan, and Eriksson 2014). These studies focus mainly on the experience of immigrants to the US before the Depression.

\footnotetext{
${ }^{1}$ In both Canada and the United States, unemployment incidence was highest among the least-skilled, and the youngest and oldest men in the workforce (Green and MacKinnon 1988; Margo 1988; Margo 1992). In the United States, unemployment was higher among black men than white men (Sundstrom 1992), with wage convergence between these groups slowing significantly between 1920 and 1940 (Smith, 1984). The spread of marriage bars between 1930 and 1950 hindered the ability of married women to maintain careers when employment opportunities were scarce (Goldin 1992; Margo 1993). ${ }^{2}$ Wenger (1996, p. 32-33) reports compelling evidence of rising discriminatory barriers faced by Jews in clerical and professional employment in Depression-era New York City.
} 
By the time the Depression hit, the immigrant population in North America was a mix of recent arrivals and well-established migrants from earlier decades. If the relative earnings of seasoned immigrants fell relative to the native-born in 1930 and 1931, the apparent assimilation during the pre-war and 1920s booms could be interpreted, at least in part, as a temporary product of the business cycle rather than a more enduring process of labour market integration. Exactly this possibility is suggested by the experience of black-white income gaps in the United States; even the more experienced cohorts of ethnic minority men fell further behind their white counterparts behind during the Depression (Smith 1984, p. 695). Beyond fragmentary evidence on unemployment, however, there is little evidence on what happened to immigrant cohorts in Depression-era labour markets.

This paper uses recently released random samples of the Canadian censuses of 1911, 1921, and 1931 to document the entry position and longitudinal labour market experiences of immigrant cohorts, relative to the native-born, before and during the Great Depression. The Canadian labour market is especially interesting for two reasons. First, Canada was one of the world's leading immigrant destinations in the first decades of the twentieth century, with approximately 4.6 million immigrants arriving in Canada between 1901 and 1931. ${ }^{3}$ As in the United States, source countries for Canadian immigration were changing over this period. Prior to 1901, the vast majority of immigrants to Canada arrived from Britain. In the early $20^{\text {th }}$ century, increasing numbers came from more distant origins in Eastern and Southern Europe. Second, the Canadian census collected 'earnings' information in each enumeration from 1901 to 1931 . These data allow us to examine the size and evolution of immigrant earnings differentials. Previous research on assimilation among immigrants of different origins (Minns 2000; Abramitzky, Boustan, and Eriksson 2014) is limited to the US and assessed via shifts in occupational profiles. For Canada, we can examine earnings directly in a way that takes account of changes in occupations and changes in pay within and between occupations. We compare earnings at arrival and earnings growth among immigrants from different countries of origin, using successive cross-sections to follow cohorts over time. To the best of our knowledge, we provide the first systematic evidence on Canadian immigrant outcomes between

\footnotetext{
${ }^{3}$ Roughly 22 percent of the Canadian population was foreign born circa 1910, a share that lies below New Zealand and Argentina ( 30 percent) but above Australia and the US (17 and 15 percent). (Hatton and Williamson, 2005, Table 2.2)
} 
1911 and 1971, and the first direct evidence anywhere of how immigrant earnings were affected by the Great Depression.

Our findings suggest that the Great Depression had a large negative effect on immigrants from Continental Europe. The relative earnings of this group declined precipitously in the early years of the Great Depression, particularly for older European migrants who had been in Canada more than twenty years. Others have written that the economic crises of the 1920s and 30s placed a disproportionate burden on older men (Marsh 1940, p. 316-7; Temple 1938, p.212); our evidence suggests this burden was particularly heavy among the foreign-born from Continental Europe, for whom irregular employment was a prominent feature of declining incomes.

Occupational patterns and the changing effects of ethnic residential concentration explain only a small portion of the sharp changes observed.

\section{Evaluating Immigrant Earnings}

The first studies of immigrant labour market assimilation in North America, using a single cross section of census or other labour market data, were optimistic about the capacity of immigrants earnings to converge with the native-born (Chiswick 1978, Abbott and Beach 1993). More recent studies, using repeated cross-sections to trace immigrant and native-born cohorts over time, find lower initial earnings of immigrants on arrival and more sluggish earnings growth (Borjas 1985 for the US; Baker and Benjamin 1993, Aydemir and Skuterud 2005 for Canada). The first studies of early immigrants to the US also relied on single cross-sections from the national census or state labour force surveys (Blau 1980, Hannon 1982, Hanes 1995, Hatton 1997). Minns (2000) adds an intertemporal dimension with repeated crosssections from the 1900 and 1910 censuses, while Abramitzky, Boustan, and Eriksson (2014) create a panel of migrants linked between census years using new digital resources and data linkage techniques. These studies report moderate to small entry effects among immigrants and subsequent earnings growth similar to that of the native-born. Assimilation rates were, if anything, somewhat higher for "new" immigrants from Southern and Eastern Europe (Minns 2000).

All of these studies are constrained by the absence of information on earnings in the US Census prior to 1940. As the Canadian census collected earnings 
information beginning in 1901, the Canadian economy offers a useful alternate testing ground to evaluate patterns of assimilation. Green and MacKinnon (2001) and Dean and Dilmaghani (2014) document the slow assimilation of British migrants to Canada circa 1901 and 1911. Little is known, however, about the earnings adjustment progress of immigrants from other parts of the world, or how immigrants in general were affected by changing labour market conditions after $1911 .{ }^{4}$ As in the US, Canada experienced changes in the volume and sources of immigrants. The foreignborn share of population rose from 13 percent in 1901 to 22 percent in 1921 and 1931 (Table 1). Most of the increase came from so-called 'free migrants' (the US and Great Britain, especially England) and 'non-preferred migrants' from Eastern Europe. The number of Canadians born in Poland and what became the Soviet Union increased from 30,000 in 1901 to more than 300,000 in 1931.

The change in source countries raised concerns about immigrant skills and adaptability. ${ }^{5}$ Contemporary observers speculated that relative poverty might have hindered immigrant economic prospects once in Canada. ${ }^{6}$ These discussions fuelled the demand for more restrictive immigration policy. Canada followed the US with the introduction of a literacy test in 1919 and formal restrictions by country of origin in 1923. The Canadian policy regime retained easy access for prospective immigrants from Britain, the Irish Free State, the United States and Northern and Western Europe (Scandinavia, Belgium, France, Holland, Switzerland, and from 1924, Germany). Immigrants from Southern and Eastern Europe faced stiffer entry conditions for direct entry to Canada, although over 185,000 Eastern Europeans were recruited by the Canadian Pacific Railroad and Canadian National Railroad under the railway agreements between 1925 and 1929. While the stated objective of the policy was to recruit prospective farmers, many ultimately ended up working in industrial occupations, not least for the railway companies themselves (Avery, 1979)

The immigrant earnings experience depends on labour market conditions as well as individual characteristics (Chiswick et al. 1997; Chiswick and Miller 2002;

\footnotetext{
${ }^{4}$ One exception to the British focus is the Armstrong and Lewis (2012) consideration of the characteristics of Dutch immigrants 1925-1929.

${ }^{5}$ Immigration Minister Clifford Sifton in 1920 expressed concern for a declining quality of English migrants (quoted in Avery, 1979, p. 96-97), although Reynolds (1935, p. 98-99) countered that skilled tradesmen were being replaced by white-collar clerical and professional immigrants.

${ }^{6}$ In Strangers within our Gates (1908), J.S. Woodsworth contrasted the difficulties of "Canadianizing" a recent influx of Galician immigrants from Eastern Europe (p. 134) with the "sober, industrious, and thrifty" Scandinavians, who were "in every way excellent citizens" (p. 97). Similar comments appear in Marsh (1940) a generation later.
} 
MacDonald and Worswick 1999; Aydemir and Skuterud 2005). Assessments of the impact of local conditions are mixed, although the most recent research finds significant effects when location decisions are exogenous (Åslund and Rooth 2007). All of these studies consider relatively mild episodes of unemployment, in the presence of some degree of public assistance for the unemployed. Labour market conditions in Canada for the 12 months leading up to the 1931 census were of an entirely different magnitude.

Canada experienced a Great Depression as deep as that of the United States, with only limited, local relief available to those unable to secure employment (Marsh 1940; MacKinnon 1988; Zagorsky 1998). By the time of the 1931 enumeration the adverse shock to labour demand already had serious consequences for the employment of unskilled workers (Marsh 1940). By June 1931 unemployment was over 20 percent, and about half of workers in the construction trades had experienced a spell out of work (Table 2). Immigrants were more likely to lose their job than if they had remained at home, as peak and average 1930s unemployment rates were higher in Canada than most of Europe (Newell and Symons, 1988). ${ }^{7}$

The massive scale of dislocation in 1931 may have had a differential impact on immigrant populations relative to the native born. In this period many immigrants used ethnic networks to arrange employment; it is unknown how well these continued to function once labour demand fell sharply. More generally, if immigrant labour faced different search costs than the native-born, we would predict that this translated into differences in unemployment, spells out of the labour market, and the willingness to accept lower wage offers. These effects could "scar" new entrants, as discussed in the contemporary literature, but there may also be substantial effects on long-settled migrants, who would face the same difficulties as older native-born Canadians, with the added disadvantage associated with job search as an ethnic minority.

\section{Data and baseline regression results}

\footnotetext{
${ }^{7}$ While we focus on the effects on labour markets during the Great Depression, it is worth noting that incomes and prices also fluctuated 1919-1922 (Leacy et al, 1983, F153-F178). The severity and duration of impact of this earlier shock on labour markets is uncertain. Survey-based estimates put unemployment at less than 10 percent in 1921 (MacLean et. al, 1931), More reliable data from the Census shows that weeks employed for prime age men were on average over 46 in 1920-21, and 42 or less in 1930-31 (Green and MacKinnon, 1988, Table 10.6).
} 
We explore immigrant adjustment in new Canadian census samples from 1911, 1921, and 1931. Each is a representative random sample from the original census manuscripts for the enumerations of 1911 (five percent), 1921 (four percent) and 1931 (three percent). ${ }^{8}$ These enumerations provide a wide range of information on personal and demographic characteristics as well as occupation and earnings. ${ }^{9}$ In our analysis we focus on a small set of explanatory variables related to human capital accumulation and interregional differences in earnings: province or region of residence, age (our proxy for experience) and the ability to speak English. The strength of our data is the rare glimpse into the earnings of immigrants in the early $20^{\text {th }}$ century. ${ }^{10}$

We restrict our attention to adult men aged 16 to 65 who report positive earnings in urban areas (census places with a population of 1,000 or higher), for two reasons. First, the proportion of adult men with positive earnings responses was much higher in urban areas. By excluding rural areas from the samples, we lose less than ten percent of all observations reporting positive earnings. For rural residents who did report earnings, the representativeness of the figures are questionable. Agriculture was the primary occupation in rural Canada, and less than a quarter of farmers reported a figure for earnings in any of the three Censuses. Consequently we also exclude all men employed in agriculture. Thus we focus on employee labour markets, for which earnings data are more complete and theories of immigrant assimilation have greatest relevance. ${ }^{11}$ A second reason to focus on urban employees is the possibility of differences in urban-rural migration between immigrants and the nativeborn, particularly once the Depression hit. Articles and correspondent notes in the

\footnotetext{
${ }^{8}$ Data descriptions are available at http://www.canada.uottawa.ca/ccri/CCRI/. Access to the data is through Statistics Canada's Research Data Centres (RDCs). Disclosure restrictions applied to these data mean that we cannot report all summary statistics, as seen in Appendix Tables A2 and A3.

${ }^{9}$ In the Appendix Section I we outline how we used price evidence to place earning into real terms. 10 The data have some limitations. In particular, our only measure of human capital is the ability to read and write. This is disappointing since post-1900 immigrants from "new" source countries in Southern and Eastern Europe likely arrived with less human capital than earlier immigrants, and yet the Canadian census provides no measure for this.

${ }^{11}$ We have also estimated our regression results limiting the sample to those who state that they are "employees." This restriction has little effect on our results. The broader urban restriction may have more substantial consequences, since a larger share of Canadian-born than immigrant men were farming. If farmer earnings were on average low, as fragmentary evidence from the Census suggest they were, then our results will overstate the distance between native-born and immigrant earnings (Inwood, MacKinnon and Minns 2014). Many immigrants coming to Canada may have worked on farms for a short period after arrival, particularly from the mid-1920s for those entering under the railway agreements. It is possible that there is disproportionate mobility out of agriculture among immigrants that we do not observe in the Census windows.
} 
Canadian Labour Gazette in 1930 and 1931 feature much discussion about "back to the land" movements in both Eastern and Western Canada directed primarily at the native-born. ${ }^{12}$

Basic summary statistics are provided in Appendix Tables A2 and A3, which summarize key population characteristics and mean log earnings for immigrants and native-born Canadians in each Census sample. To trace the evolution of relative immigrant earnings over time, we estimate a relatively parsimonious series of regression models, as outlined in the following equation:

$Y_{i j}=\alpha 0_{i j}+\beta 1 a g e_{i j}+\beta 2 a g e_{i j}^{2}+\gamma 1 y s m_{i j}+\gamma 2 y s m_{i j}^{2}+I_{i j} \theta+X_{i j} \chi+\varepsilon_{i j}$

In equation (1), $Y$ is the log of personal earnings in year $i$ and age cohort $j$. Our first estimates use annual earnings (consistent with the existing literature on immigrant assimilation in early $20^{\text {th }}$ century labour market). On the right-hand side, age and the square of age are proxies for experience. Years since migration (ysm) approximates the Canadian-specific labour market experience of immigrants. ${ }^{13}$ Our analysis of immigrants of different origins divides the foreign-born population into three broad groups, based on 1920s Canadian immigration policy criteria - immigrants who enjoyed free entry into Canada after 1921 (Britain, Ireland, and the US), "preferred" immigrants from Northwest Europe (France, Netherlands, Belgium, Germany, and "non-preferred" immigrants from other origins. ${ }^{14}$ Separating preferred from nonpreferred allows the second group to consist mainly of immigrants from the same origins as "new" immigrants in the United States post-1895. These immigrant indicators are included in equation (1) through the vector $I$. Finally, $X$ is a vector of control variables - in the baseline specification, these are province of residence, and a

\footnotetext{
12 The 1936 Census of Manitoba suggests that such movement began to take place between 1931 and 1936 (Marsh 1940). By March 1932, less than 45 thousand urban residents had been relocated to farming communities as part of "back to the land" policies (Labour Gazette, 1932, p. 293, p. 511). Our data reveal little evidence of strong movement either towards or away from rural areas between 1921 and 1931, for either immigrants or the native-born.

${ }^{13}$ We have experimented with more flexible specifications that allow the returns to experience in Canada to vary across immigrant groups. These results are broadly similar, with almost all of the ysmimmigrant group interactions yielding small and statistically insignificant coefficients. ${ }^{14}$ We include Germany in the list of preferred countries from 1924, in which year it changed from the
non-preferred to the preferred category.
} 
dummy variable for lack of English language ability. ${ }^{15}$ We estimate the model in equation (1) for all three Census years ( $i=1911,1921$, or 1931), and for three age cohorts (j=born 1876-85, born 1866-75, or born 1856-65). The regression coefficients on immigrant origins, age, and years since migration allow us to trace the evolution of relative immigrant earnings between census years, as captured through the cohort dummies.

Main results are presented in Table 3. Appendix Table A4 includes additional controls for province of residence. Our main interest is to infer predicted relative earnings using the pattern of coefficients on the immigrant indicators, age, and years since migration. As is typical of most age earnings profiles, the quadratic age terms show decreasing returns to experience. Unsurprisingly, the age/earnings slope is usually steeper at early ages among younger cohorts. Provincial indicators show earnings were higher in Quebec than Ontario for all age cohorts in most census years. In large part this reflects the fact that Montreal was the economic centre of the country throughout these years. Maritimers typically had lower earnings then Ontarians, which is also consistent with expectations based on alternative sources. ${ }^{16}$ For Western Canada the picture is more mixed. A positive premium is found in British Columbia in 1911, but not in 1921 or 1931. In the Northwest (Alberta, Saskatchewan, and urban settlements in the Yukon), we find positive premiums in 1921 and 1931. Earnings in 1911 urban Manitoba are in line with those in Ontario.

The indicator for lack of English language ability is the most interesting of the control variables. Coefficients are negative, significant, and large in all nine regressions, and are much greater in magnitude in 1931 for all cohorts than in 1911 or 1921. Apparently the benefit conferred by language human capital grew over time, and was particularly large in the depressed conditions of the early 1930s. We hypothesize that those with higher search costs due to poor communication skills and a heavy reliance on ethnic networks were especially disadvantaged by the declining demand for labour. Other findings later in this paper will support this view of the immigrant labour market in 1931.

\footnotetext{
15 The language indicator is a dummy variable set to 1 if the individual cannot speak English, and zero otherwise.

${ }^{16}$ See Inwood, MacKinnon, and Minns (2014) for evidence on regional earnings from the Census of 1901 and 1911, and Emery and Levitt (2002) on wage evidence from the Labour Gazette in the 1910s, 20 s, and 30 s.
} 
The dummy variables for "free", "preferred", and "non-preferred" migrants provide the predicted earnings gap between each immigrant group and otherwise identical native-born Canadians on arrival. The estimated entry effects are large for all groups and age cohorts in 1911 and 1921 (in the order of 25 to $60 \log$ points). The entry effect is much larger in 1931 especially for European migrants in the preferred and non-preferred groups.

Figures $1 \mathrm{a}$ and $1 \mathrm{~b}$ illustrate the relative progress of age-arrival cohorts over time. We use the regression results to simulate the earnings path of two age and arrival cohorts relative to the native-born. In each case, we use coefficient estimates to track the progress between censuses of immigrants relative to the native-born of the same age, both resident in Ontario throughout and able to speak English. Figure 1a compares just-arrived immigrants (years since migration $=0$ ), who were 25 years of age in 1911 to native-born men of the same age. Figure $1 \mathrm{~b}$ does the same for immigrants who arrived in 1896 (years since migration $=15$ ), who were 40 years of age in 1911. In each figure, we follow the fortunes of the three aggregate immigrant groups (free, preferred, and non-preferred) over the 20 year window. ${ }^{17}$

Both figures show that free immigrants, largely from the US and the UK, made reasonable progress after 1911, despite the large entry penalty experienced by younger migrants (Figure 1a). This pattern suggests that the reported trend of British immigrants faring poorly in Canada in 1901 and 1911 ceased to be the case after the First World War (Green and MacKinnon 2001; Dean and Dilmaghani 2014). Progress for other immigrants was more limited. Preferred and non-preferred immigrants did not come close to achieving earnings parity with the native-born. A striking feature of all three figures is "reverse assimilation", with the divergence in earnings between preferred and non-preferred immigrants and comparable native-born between 1921 and 1931, particularly among the older immigrant groups. The predicted earnings gaps in 1931 are in the order of 30 to 90 log points, a disadvantage much larger than found among experienced immigrants in Canada in 1901 and 1911 (Green and Mackinnon 2000; Dean and Dilmaghani 2014), and larger than comparable wage gaps observed in recent decades (Aydemir and Skuterud 2005; Borjas 1994a).

\footnotetext{
${ }^{17}$ Regression models without controls for language generate similar results (available on request).
} 


\section{Explaining "Reverse Assimilation"}

\section{(i) Selective Outmigration}

What explains the sharp decline in immigrant earnings to 1931? Return to Europe was an important part of early $20^{\text {th }}$ century mass migration (Kuznets and Rubin 1954; Bandiera, Rasul, and Viarengo, 2013), and it may contribute to any apparent intertemporal adjustment in earnings (see Abramitzky, Boustan, and Eriksson, 2014, Figure 1). The Canadian case introduces another form of potentially selective attrition, that being the departure of native-born Canadians and immigrants to Canada to the United States (McInnis 2000b; Ramirez 2001; Widdis 1998)

While we have little capacity to control formally for this problem, some evidence is available for return migration to Britain from Canada, and migration from Canada to the United States. Setting aside the First World War, the number of Britons returning the UK from Canada declined gradually between 1900 and 1935, with the annual average falling from 24 thousand between 1900 and 1913 to a little under 15 thousand between 1925 and $1935 .{ }^{18}$ Occupational data from 1925 to 1937 show that until 1930, both skilled professionals and labourers were overrepresented among return flows relative to outward-bound migrants. The composition of return flows changed little under Depression conditions between 1931 and $1937 .{ }^{19}$ The Canadian Census Bureau reported that outflows of the Canadian-born to the United States declined markedly after $1924 .^{20}$ This implies that the relative position of the nativeborn is less likely to reflect selective migration decisions among cohorts affected by the Great Depression than might have been the case in earlier decades. ${ }^{21}$ Moreover,

\footnotetext{
${ }^{18}$ Carrier and Jeffrey (1953, p. 97, Table D/F/F (2).

${ }^{19}$ Carrier and Jeffrey (1953, p. 116, Table N/O (3)). Between 1925 and 1930, 57 percent of return migrants were professional or skilled workers, and 18 percent labourers. From 1931 to 1937 the corresponding shares were 59 and 16 percent.

${ }^{20}$ Decadal emigration rates from Canada were well over 100 per 1000 through the late $19^{\text {th }}$ century (McInnis 2000a; 2000b). Emigration from Canada to the United States fell from approximately 201 thousand in the fiscal year ending June 30 1924, to less than 75 thousand in the year ending June 1929, before collapsing to only 18 thousand over six months July-December 1930. (Labour Gazette, 1929, p. 312; Labour Gazette, 1930, p.44; Labour Gazette, 1931, p. 375). Return migration to Canada also fell as the Depression began to unfold, with US to Canada flows declining from about 3 thousand a month in 1930 to less than 1.5 thousand per month in 1931 (Labour Gazette, 1930, p. 375; Labour Gazette, 1931, p. 1133

${ }^{21}$ We have estimated our regression models in a more restricted sample in which the native-born include only internal migrants, and we find larger native born - immigrant differentials under this alternative. Our tentative interpretation of these results is that the departure of those who left to the US is likely to compress earnings differentials relative to a counterfactual in which Canadian emigrants were unable to move south.
} 
many of our most striking results are from regressions focusing on the relative performance of older immigrants who had extensive labour market experience in Canada by 1911 or 1921 . Given the strong negative correlation between (adult) age and migration, selection issues due to return migration are less likely to be important for those already over the age of 40 in 1911. A similar argument applies for the emigration of native-born Canadians to the United States.

As a final check on the possible impact of unobserved return migration on our findings for 1931, we perform a back of the envelope calculation for the level of mean earnings by return migrants needed to overturn the pattern of "reverse assimilation" seen for non-preferred migrants between 1921 and 1931. ${ }^{22}$ Assuming a high return migration rate of 25 percent, the mean earnings of return migrants in the 1886-95 birth cohort would have to be $\$ 1034$ for non-preferred earnings growth to match that of free migrants between 1921 and 1931. This is almost double the earnings (\$598) of those actually present in Canada in 1931. For the oldest cohort born 1866-75, the earnings of return migrants under the same simulation would be $\$ 737$, which is a 50 percent premium above those who were present in 1931 (\$489). It is unlikely, however, that return migration rates were anywhere near that high for a cohort with an average age of over 50 in 1921; with a more modest rate of departure of 10 percent we find that those leaving would have to earn an average of \$1108 if in Canada to march free immigrant earnings growth in the same cohort. This is sufficiently implausible to imply that selective return migration is unlikely to be the main source of "reverse assimilation".

\section{(ii) Occupation and skills mismatch}

A second possibility is that immigrants suffered a particularly strong penalty from changing returns to job-specific skills between 1921 and 1931. This would be the case if the foreign-born worked disproportionately in sectors of the economy that grew quickly 1921 only to be hit especially hard in 1931 . The simplest way to explore this possibility is by extending our baseline specification to control for occupation. A further contribution of this approach is that it allows us to observe the extent to which immigrants experienced earnings convergence within occupation, an

\footnotetext{
${ }^{22}$ We draw upon mean earnings by census year and birth cohort from Appendix Table A2 for these calculations.
} 
issue which previous studies have had to set aside due to data constraints (Minns 2000; Abramitzky, Boustan, Eriksson 2014) .

Table 4 reports the full set of coefficients from the modified regressions, including the occupation controls. A visual summary is provided in Figures 2a and 2b. We use the same assumptions regarding age, vintage (years since migration), language ability, and province or residence as in Figures $1 \mathrm{a}$ and $1 \mathrm{~b}$, and make predictions conditional on being employed in the operative category.

Controlling for occupation accounts for a noticeable share of the earnings gap between preferred/non-preferred immigrants and the native-born among younger workers (Figure 2a). For older immigrants, however, the earnings penalties remain substantial in 1931 - Figure $2 \mathrm{~b}$ reports gaps of 80 to $85 \log$ points for preferred and non-preferred migrants aged 40 in 1911 with an 1896 arrival date. Thus, while occupational controls account for a substantial portion of the earnings penalty suffered by younger and more recently arrived immigrants, older migrants suffered large earnings disadvantages even within occupations. This step also suggests that differences in earnings between free (mainly Anglophone) immigrants and their Canadian counterparts were small within occupations. This finding qualifies the claims of contemporaries (and current historians) that English and Irish immigrants suffered the effects of labour market discrimination in Canada. Free immigrants, who were dominated by arrivals from the British Isles, had relatively lower wages because of their occupational mix but that earnings within occupations converged toward those of the native-born.

\section{(iii) Unemployment and Time Worked}

Growing native-born immigrant differences in 1931 in annual earnings may have been a reflection of increasing gaps in employment between ethnic groups once the Depression hit. While the literature on ethnicity and unemployment in 1930s Canada is limited, it does suggest that foreign-born groups were disadvantaged. Marsh's analysis shows that the incidence of unemployment was greatest the lowskilled occupations, particularly construction (Marsh 1940, p. 298, p. 364) ${ }^{23}$ His findings also confirm international patterns of greater unemployment among older workers. Green and MacKinnon (1988) show that the share of men who lost time in

\footnotetext{
${ }^{23}$ Unemployment rates were less than 10 percent for clerks and store managers, and over 50 percent for labourers and carpenters.
} 
1931 varied by country of birth. Forty-four percent of working-age men lost time in 1930-31. For British immigrants, the figure is 50 percent for recent arrivals, and 40 percent for those in Canada since 1911. For European immigrants the equivalent numbers are 71 percent and 52 percent.

We estimate weekly earnings regressions without occupation controls (Table 5), then add these controls (Table 6) and use the second set of results to trace earnings gaps relative to the native born over the life-cycle for the three cohorts of interest (Figures $3 \mathrm{a}$ and $3 \mathrm{~b}){ }^{24}$ Removing the effect of spells without work significantly attenuates the earnings gaps between the native-born and immigrants (both preferred and non-preferred). This is particularly clear in 1931, where the hardest-hit cohorts are now within $25 \mathrm{log}$ points of the native-born (Figure $3 \mathrm{~b}$ ). ${ }^{25}$ While it is clear that much of the large gap found in the earlier figures was due to relative differences in lost work-time, an earnings disadvantage of 20 to 25 percent remains significant by historical standards, and we still find little convergence for preferred and nonpreferred migrants between 1911 and $1931 .^{26}$

\section{(iv) Language Skills and Ethnic Networks}

Immigrant skills, and changes in how those skills were perceived and rewarded in Canadian labour markets, may offer another possible explanation for the relative earnings divergence seen in 1931. In particular, immigrants with limited language ability may have had a particularly difficult adjustment once the Depression hit and searching for scarce employment became crucial. Our results thus far show that the penalty for being unable to speak English was substantially higher in 1931 than in 1911 or 1921, but this cannot account for the decline in relative immigrant earnings holding English language ability constant. To explore the dynamics of

\footnotetext{
${ }^{24}$ The Canadian census collected information on weeks worked in occupations in 1911, weeks away for any reason in 1921, and derived weeks away for any reason in 1931. We sum weeks in all occupations in 1911, and subtract weeks lost in 1921 and 1931 from 52 to arrive at a number of weeks worked which we then use as the denominator in calculating weekly earnings. Sample coverage of weeks worked/not worked is excellent in both 1911 and 1931, but limited to about 65 percent of observations in 1921.

${ }^{25}$ Controlling for weeks worked also has a substantial effect on earnings gaps in 1911, which may indicate that differences in job attachment help to explain findings of slow assimilation among immigrants to Canada prior to the First World War.

${ }^{26}$ The predicted earnings gaps in 1931 for free, preferred and non-preferred in figure 3a are .027, -.045, and -.130 . The standard errors on the predicted values are $.025, .046$, and .029 , which suggests a significant earnings gap to the native-born for the non-preferred. Similarly, in figure $3 \mathrm{a}$, predicted earnings gaps in 1931 for older migrants in figure $3 \mathrm{~b}$ are $-.135,-.279$, and -.331 , and the corresponding standard errors .153, .160, and .148.
} 
capabilities in both English and French more closely, we estimate (not shown) a series of regressions that interact the ability or inability to speak English with region of residence. In these regressions, we find that the absence of English language ability was somewhat more detrimental in Western Canada than in Ontario, perhaps consistent with the West having fewer large industrial employers. It does not appear, however, that the penalties were less severe in francophone Quebec. This last finding is consistent with evidence of high returns to language ability in early $20^{\text {th }}$ Century Montreal (MacKinnon, 2000). We find little evidence of earnings penalty associated with a lack of French language ability. ${ }^{27}$

Changing attitudes towards the employment of European immigrants as the Depression deepened may also have disrupted the ability of long-standing migrants to use ethnic networks to access the labour market as they had done previously. Several scholars have debated the role of "ethnic capital" in the immigrant adjustment process (Borjas 1994b; 1995). If claims by some US historians that labour market discrimination against immigrants increased during the Depression are correct (Wenger, 1996), then such discrimination may have manifested itself in the labour market by reducing the value of co-ethnic connections, especially in securing wellpaid new employment after a spell without a job.

We explore the role of ethnic networks in the Canadian context through regressions models for 1921 and 1931 that include immigrant own-ethnic concentration as a right-hand side variable. The ethnic concentration variable consists of the population share in the town or city of residence with the same foreign birth country. Shares are constructed from published Census tabulations for available towns and cities with populations over 7500. Sample size is therefore somewhat reduced from previous estimations. Table 7 presents the results of the key coefficients of interest for models of annual and weekly earnings including occupation controls - origin dummy variables, and ethnic concentration variables for free, preferred, and non-preferred origin immigrants. We find that for free migrants, the positive impact of own concentration on annual earnings see only moderate change between 1921 and 1931. For the youngest, most recently arrived cohort, own concentration effects are stable. Only for the oldest cohort is there significant decline, though the sign of own concentration remains positive throughout. For preferred and

\footnotetext{
${ }^{27}$ These regression results are available from the authors on request.
} 
non-preferred migrants, there are sharper changes in the relationship between own concentration and earnings, with greater co-ethnicity switching from being positively to negatively related to individual earnings. Taking marginal effects at face value, for the cohort of 1901 arrivals, residence in a town with 3 percent own ethnic concentration would raise relative earnings by six percentage points in 1921, but reduce relative earnings by three percentage points in 1931. For the oldest group the findings are more stark, though the coefficient estimates are also less precise, with three percent co-residence switching from reducing gaps by 14 percentage points in 1921 to increasing gaps by 12 percentage points in 1931 . These represent 35 percent and 24 percent of the predicted earnings gap for those residing in a town with no members of the same ethnic community.

Some caution is needed in reading these results: quite clearly, one would expect immigrant residential choice to depend on earnings in the first place, and much of the earnings decline between 1921 and 1931 appears to remain unrelated to changing returns to immigrant concentration. General labour market discrimination against immigrants, and particular changes in the intensity of discrimination experienced, may well contribute to the persistent earnings decline we find. But the findings in Table 7 do suggest one way the Depression harmed the easily identifiable foreign-born was through disrupting a previous routes to immigrant labour market success.

\section{Discussion and Conclusions}

Using a synthetic cohort approach we find that immigrants experienced an earnings disadvantage at entry which diminished during the war decade 1911-1921. The extent of convergence is greater than suggested by previous studies of labour markets in early twentieth Canada. The experience varied by source country; American and British migrants fared much better than workers from Southern and Eastern Europe. We also see a strong differential impact of the Great Depression on immigrant earnings profiles. "Free" migrants from the US and UK continued their catch-up growth relative to the native-born through to 1931. Other immigrants fared much worse. The most striking finding is a pattern consistent with "reverse assimilation" between 1921 and 1931, with declining earnings relative to the nativeborn, particularly for long-settled, older workers. Occupational controls do little to alter this finding. Shifting the focus from annual to weekly earnings does account for 
a sizeable share of the observed relative earnings decline. For older cohorts, the log point earnings differential falls by about two-thirds in 1931 when we run regressions explaining weekly earnings rather than annual earnings, but this remains a significant gap to native-born earnings, especially when compared to other periods in the twentieth century.

What accounts for these findings? One possibility relates to post-migration human capital investments. Immigrants arriving with fewer skills may have made different investments than natives and native-speakers in terms of general versus jobspecific skills. Credit constraints among poorer European immigrant families may have directed their human capital investment in earlier years to job-specific skills. If so, the disruption in the labour market between 1929 and 1931 would have hit these groups particularly hard. In line with this view, we find that earnings penalties associated with the inability to speak English were substantially higher in 1931. Were this to be the only explanation, however, one would expect occupational controls to explain more of the earnings gaps and in particular the earnings deterioration between 1921 and 1931. Thus, an immigrant-specific human capital acquisition strategy cannot be the only force at work.

Our results show that part of the reason immigrant earnings deteriorated rapidly when labour demand was at its most slack may have been disruptions to the role of ethnic networks in securing employment for migrants from Continental Europe. It is difficult to say to what extent this reflected an underlying increase in exposure to labour market discrimination when employment opportunities were rationed. A discrimination-based explanation that focuses mainly on migrants from Continental Europe is not entirely consistent with the historical literature emphasizing the hostility of many native-born Canadians towards arrivals from Britain in the early $20^{\text {th }}$ century (Lloyd 2012). While we provide important new evidence of "reverse assimilation" during the Great Depression, a full analysis of the immigrant labour experience remains an important question for future research and additional data that ideally would combine direct evidence of earnings and richer detail for skills and human capital. 


\section{References}

ABBOTT, M.G., BEACH, C.M. (1993). Immigrant Earnings Differentials and BirthYear Effects for Men in Canada: Post-war-1972. Canadian Journal of Economics 26, 505-524.

ABRAMITZKY, R., BOUSTAN, L.P., ERIKSSON, K. (2014). A Nation of Immigrants: Assimilation and Economic Outcomes in the Age of Mass Migration. Journal of Political Economy 122, 467-717.

ARMSTRONG, A., LEWIS, F.D. (2012). International Migration with Capital Constraints: Interpreting Migration from the Netherlands to Canada in the 1920s. Canadian Journal of Economics 45,732-754.

ÅSLUND O., ROOTH, D.-O. (2007). Do when and where matter? Initial labour market conditions and immigrant earnings. The Economic Journal 117, 422-448.

AVERY, D. (1979). "Dangerous Foreigners": European Immigrant Workers and Labour Radicalism in Canada 1896-1932. Toronto: McClelland Stewart.

AYDEMIR, A., SKUTERUD, M. (2005). Explaining the Deteriorating Entry Earnings of Canada's Immigrant Cohorts, 1966-2000. Canadian Journal of Economics 38, 641-672.

BAKER, M., BENJAMIN, D. (1994). The Performance of Immigrant in the Canadian Labour Market. Journal of Labor Economics 12, 369-405.

BANDIERA, O., RASUL, I., VIARENGO, M. (2013). The Making of Modern America: Migratory Flows in the Age of Mass Migration. Journal of Development Economics 102, 23-47.

BARRETT, A., KELLY, E. (2012). The Impact of Ireland's Recession on the Labour Market Outcomes of its Immigrants. European Journal of Population/Revue européene de Démographie 28, 91-111.

BLAU, F.D. (1980). Immigration and Labor Earnings in Early Twentieth Century America. Research in Population Economics 2, 21-41.

BLOOM, D.E., GRENIER, G., GUNDERSON, M. (1995). The Changing Labour Market Position of Canadian Immigrants. Canadian Journal of Economics, 28, 9871005.

BORJAS, G.J. (1985). Assimilation, Changes in Cohort Quality, and the Earnings of Immigrants. Journal of Labor Economics 3, 463-489.

BORJAS, G.J. (1994a). The Economics of Immigration. Journal of Economic Literature 32, 1667-1717.

BORJAS, G.J. (1994b). Long-Run Convergence of Ethnic Skill Differentials: The Children and Grandchildren of the Great Migration. Industrial and Labor Relations Review 47, 553-573. 
BORJAS, G.J. (1995). Ethnicity, Neighborhoods, and Human-Capital Externalities. American Economic Review 85, 365-390.

CANADA (1929-1932). Labour Gazette. Ottawa: Department of Labour.

CARRIER, N.H., JEFFERY, J.R. (1953). External Migration, A Study of the Available Statistics, 1815-1950. General Register Office Studies on Medical and Population Subjects, no. 6. London: Her Majesty's Stationary Office.

CHISWICK, B.R. (1978). The Effect of Americanization on the Earnings of Foreignborn Men. Journal of Political Economy 8, 897-921.

CHISWICK, B.R. (1986). Is the new immigration less skilled than the old?.Journal of Labor Economics 4, 168-192.

CHISWICK, B.R., COHEN, Y., TZIPPI, Z. (1997). The labor market status of immigrants: effects of the unemployment rate at arrival and duration of residence. Industrial and Labor Relations Review 50, 289-303.

CHISWICK, B.R., MILLER, P.W. (2002). Immigrant earnings: Language skills, linguistic concentrations and the business cycle. Journal of Population Economics 15, $31-57$.

DEAN, J., DILMAGHANI, M. (2014). Economic Intergration of Pre-WWI Immigrants from the British Isles in the Canadian Labour Market. Journal of International Migration and Integration 15, 1-22.

DOUGLAS, P.H. (1919). Is the new immigration more unskilled than the old? Quarterly Publications of the American Statistical Association 16, 393-403.

EMERY, J.C.H., LEVITT, C. (2002). Cost of Living, Real Wages, and Real Incomes in Thirteen Canadian Cities, 1900-1950. Canadian Journal of Economics 35, 115137.

GOLDIN, C. (1992). Understanding the Gender Gap. Oxford: Oxford University Press.

GEMERY, H.A. (1993). International migration and the US labor market in the Great Depression. In: Hatton, T.J., Williamson, J.G. (eds.) Migration and the International Labor Market 1850-1939, London: Routledge, 175-199.

GREEN, A.G., GREEN, D.A. (1995) Canadian Immigration Policy: The Effectiveness of the Point System and Other Instruments. Canadian Journal of Economics, 28, 1006-1041.

GREEN, A.G., MACKINNON, M.E. (1988). Unemployment and Relief in Canada. In: Eichengreen, B.J., Hatton, T.J. (eds.) Interwar Unemployment in International Perspective. Amsterdam: Springer Netherlands, pp. 353-396. 
GREEN, A.G., MACKINNON, M.E. (2001). The Slow Assimilation of British Immigrants in Canada: Evidence from Montreal and Toronto, 1901. Explorations in Economic History 38, 315-338.

HANES, C.K. (1995). Immigrants' Relative Rate of Wage Growth in the Late $19^{\text {th }}$ Century. Explorations in Economic History 33, 35-54.

HANNON, J. U. (1982). Ethnic Discrimination in a $19^{\text {th }}$-Century Mining District: Michigan Copper Mines: 1888. Explorations in Economic History 19, 28-50.

HATTON, T. J., (1997). The Immigrant Assimilation Puzzle in Late NineteenthCentury America. Journal of Economic History 57, 34-62.

HATTON, T.J., (2000). How much did immigrant "quality" decline in late nineteenth century America? Journal of Population Economics 13, 509-525.

HATTON, T.J., WILLIAMSON, J.G., (2005). Global Migration and the World Economy: Two centuries of Policy and Performance. Cambridge: MIT Press..

INWOOD, K., MACKINNON, M.E., MINNS, C., (2014). Labour market dynamics in Canada, 1891-1911: a first look from new Census samples. In: Darroch, G. (ed.) The dawn of Canada's century: hidden histories. Kingston and Monteal: McGillQueen's University Press, 361-395.

KUZNETS, S., RUBIN, E. (1954). Immigration and the Foreign Born. New York: NBER.

LEACY, F.H., et. al., (1983). Historical Statistics of Canada. Ottawa: Statistics Canada.

LEW, B., CARTER, B. (2002). The Impact of United States Immigration Quotas on Migration to Canada During the 1920s. Unpublished working paper, Trent University.

LLOYD, A.J. (2012). 'The Englishmen here are much disliked': Hostility towards English Immigrants in Early Twentieth Century Toronto. In: Bueltmann, T., Gleeson, D.T., Macraild, D.M. (eds.) Locating the English Diaspora, 1500-2010. Liverpool: Liverpool University Press, Liverpool, 135-149.

MACKINNON, M.E. (1990). Relief not insurance: Canadian unemployment relief in the 1930s. Explorations in Economic History 27, 46-83.

MACKINNON, M.E. (2000). Uniligues ou billingues? Les Montréalais sur le marché du travail en 1901. L'Actualité Économique 76, 137-158.

MACDONALD, J.T., WORSWICK, C. (1999). The earnings of immigrant men in Australia: assimilation, cohort effects, and macroeconomic conditions. Economic Record, 75, 49-62. 
MARGO, R.A. (1988). Interwar Unemployment in the United States: Evidence from the 1940 Census Sample. In: Eichengreen, B.J., Hatton, T.J. (eds.) Interwar Unemployment in International Perspective. Amsterdam: Springer Netherlands, 325-352.

MARGO, R.A. (1991). The Microeconomics of Depression Unemployment. Journal of Economic History 51, 333-341.

MARGO, R.A. (1992). Employment and Unemployment in the 1930s. Journal of Economic Perspectives 7, 41-59.

MCINNIS, M.A. (2000a). The Population of Canada in the Nineteenth Century." In: Haines, M., Steckel, R. (eds.) A Population History of North America. Cambridge: Cambridge University Press, 371-432

MCINNIS, M.A. (2000b). The Population of Canada in the Twentieth Century. In: Haines, M., Steckel, R. (eds.) A Population History of North America. Cambridge: Cambridge University Press, 529-600.

MARSH, L. (1940). Canadians In and Out of Work: A Survey of Economic Classes and their Relation to the Labour Market. Montreal: Oxford University Press.

MINNS, C. (2000). Income, Cohort Effects, and Occupational Mobility: A New Look at Immigration to the United States at the Turn of the 20th Century. Explorations in Economic History 37, 326-350.

MINNS, C., MacKinnon, M.E. (2007). The Cost of Doing Hard Time: A Penitentiary-Based Regional Price Index For Canada, 1883-1923. Canadian Journal of Economics, 40, 528-560.

NEWELL, A. and SYMONS, J.S.V. (1988) The Macroeconomics of the Interwar Years: International Comparisons. In: Eichengreen, B.J., Hatton, T.J. (eds.) Interwar Unemployment in International Perspective. Amsterdam: Springer Netherlands, 6196.

ORRENIUS, P.M., ZAVODNY, M. (2010). Immigrants' Employment Outcomes Over the Business Cycle. IZA Discussion Paper 5354.

RAMIREZ, B., with OTIS, Y. (2001). Crossing the $49^{\text {th }}$ Parallel: Migration From Canada to the United States, 1900-1930. Ithica: Cornell University Press.

REYNOLDS, L.G. (1935). The British Immigrant: His Social and Economic Adjustment in Canada. Toronto: Oxford University Press.

SMITH, J.P. (1984). Race and Human Capital. American Economic Review 74, 68598.

SUNDSTROM, W.A. (1992). Last Hired, First Fired? Unemployment and Urban Black Workers During the Great Depression. Journal of Economic History 50, 415429. 
TEMPLE, W. (ed.) (1938). Men Without Work: a report made to the Pilgrim Trust. Cambridge: Cambridge University Press.

WENGER, B.S. (1996). New York Jews and the Great Depression: Uncertain Promise. New Haven: Yale University Press.

WIDDIS, R. (1998). With Scarcely a Ripple: Anglo-Canadian Migration into the United States and Western Canada, 1880-1920. Kingston and Montreal: McGillQueens University Press.

WOODSWORTH, J.S. (1909). Strangers Within Our Gates. Toronto: F.C. Stephenson.

ZAGORSKY, J.L. (1998). Was depression era unemployment really less in Canada than the US? Economics Letters 61, 125-131. 
Table 1: The foreign-born in Canada, 1891-1931 (thousands)

\begin{tabular}{|c|c|c|c|c|c|}
\hline Year & Population & $\begin{array}{c}\text { Foreign-born } \\
(\% \text { of population })\end{array}$ & $\begin{array}{c}\text { Free migrants } \\
\text { (\% off foreign-born) }\end{array}$ & $\begin{array}{l}\text { Preferred migrants } \\
\text { (\% of foreign-born) }\end{array}$ & $\begin{array}{l}\text { Non-preferred migrants } \\
\text { (\% of foreign-born) }\end{array}$ \\
\hline 1891 & 4833 & $\begin{array}{l}644 \\
(13)\end{array}$ & $\begin{array}{l}572 \\
(89)\end{array}$ & $\begin{array}{l}41 \\
(6)\end{array}$ & $\begin{array}{l}31 \\
(5)\end{array}$ \\
\hline 1901 & 5371 & $\begin{array}{l}700 \\
(13)\end{array}$ & $\begin{array}{l}534 \\
(76)\end{array}$ & $\begin{array}{l}56 \\
(8)\end{array}$ & $\begin{array}{l}109 \\
(16)\end{array}$ \\
\hline 1911 & 7207 & $\begin{array}{l}1587 \\
(22)\end{array}$ & $\begin{array}{l}1118 \\
(70)\end{array}$ & $\begin{array}{l}130 \\
(8)\end{array}$ & $\begin{array}{l}339 \\
(21)\end{array}$ \\
\hline 1921 & 8788 & $\begin{array}{l}1956 \\
(22)\end{array}$ & $\begin{array}{l}1439 \\
(74)\end{array}$ & $\begin{array}{l}128 \\
(7)\end{array}$ & $\begin{array}{l}388 \\
(20) \\
\end{array}$ \\
\hline 1931 & 10377 & $\begin{array}{l}2308 \\
(22)\end{array}$ & $\begin{array}{l}1529 \\
(66)\end{array}$ & $\begin{array}{l}174 \\
(8)\end{array}$ & $\begin{array}{l}604 \\
(26)\end{array}$ \\
\hline
\end{tabular}

Source: Leacy et al. (1983).

Notes: Free migrants are arrivals from the United States, Britain, Ireland, and other British dependencies. Preferred immigrants are from Belgium, the Netherlands, France, Germany, and Scandinavia. Non-preferred immigrants include all other arrivals from Europe and elsewhere. 
Table 2: Canadian unemployment in 1931

\begin{tabular}{|c|c|c|c|}
\hline \multicolumn{2}{|c|}{ a) Unemployment by city } & \multicolumn{2}{|c|}{ b) Unemployment by occupation } \\
\hline Place & $\%$ wage earners not at work & Occupation & \% "no job" during 1930-31 (Men) \\
\hline Vancouver & 34 & Retail store managers & 6 \\
\hline London & 14 & Mechanics & 33 \\
\hline Toronto & 19 & Carpenters & 61 \\
\hline Ottawa & 14 & Truck drivers & 30 \\
\hline Montreal & 20 & Labourers & 55 \\
\hline \multirow[t]{4}{*}{ Canada } & 21 & Janitors & 13 \\
\hline & & Cooks & 32 \\
\hline & & Salesmen & 19 \\
\hline & & Office Clerks & 11 \\
\hline
\end{tabular}

Notes: Sources for panel a) are Green and Mackinnon's (1988, Table 10.2) calculations from Dominion Bureau of Statistics (1934). Sources for panel b) are Green and Mackinnon's (1988, Table 10.3) calculations from Dominion Bureau of Statistics (1934; 1935). Unemployment in panel a) is the share not at work on 1 June 1931. Unemployment in panel b) indicates the share who had no job at some time in the 1930-31 Census window. 
Table 3: Regression results, annual earnings

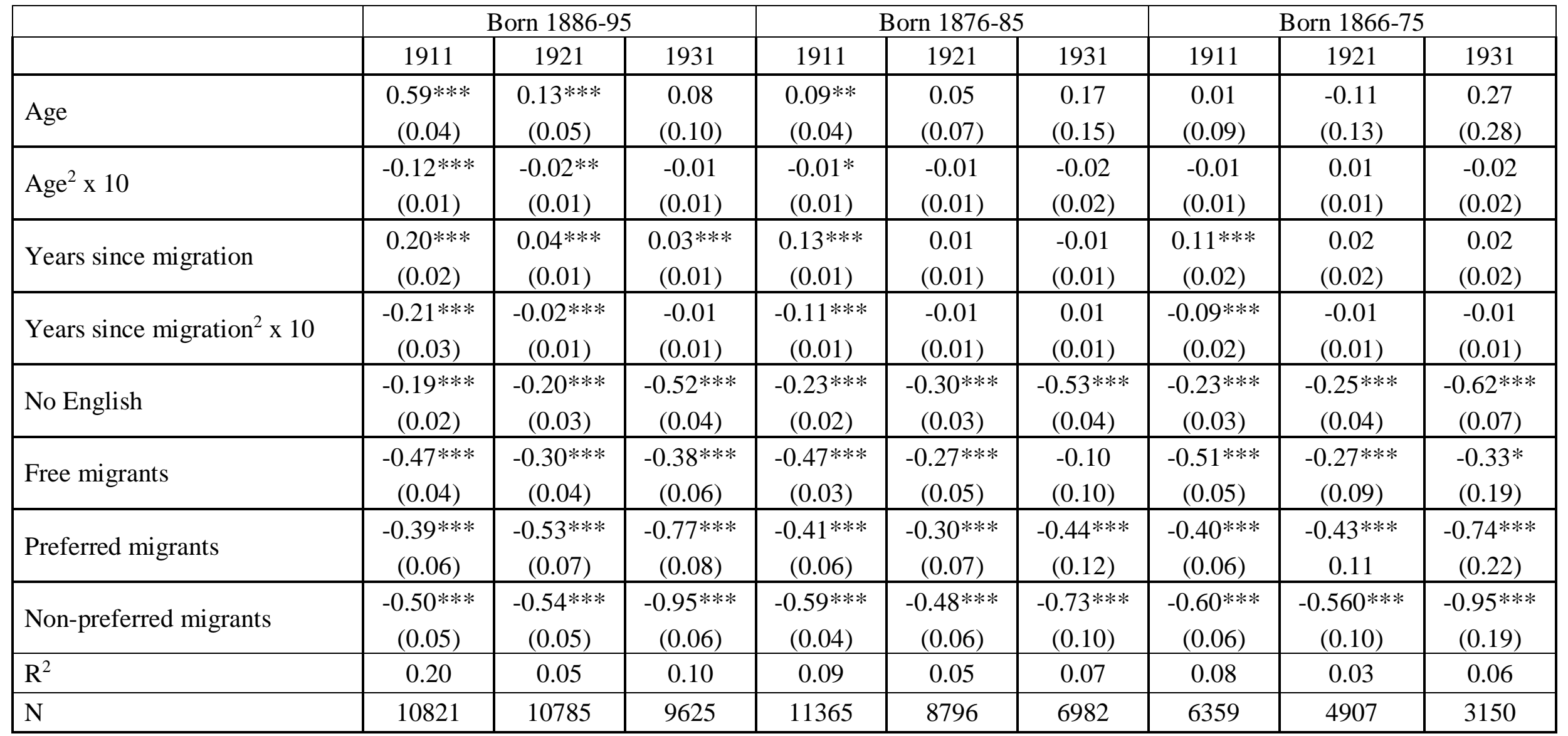

Notes: Canadian Census samples of 1911, 1921, and 1931 - see text for further details. Estimation is by OLS. Coefficients on age squared and ysm squared are scaled up by a factor of 10 . Weighted with census sampling weights. Estimates also include dummy variable controls for Province of residence and a constant term. A full list of coefficients is available in the Appendix Table A4. Heteroskedasticy-robust standard errors in parentheses. $* * *, * *$ and $*$ indicate coefficients significant at $1 \%, 5 \%$, and $10 \%$ level. 
Table 4: Regression results, annual earnings, occupation controls

\begin{tabular}{|c|c|c|c|c|c|c|c|c|c|}
\hline & \multicolumn{3}{|c|}{ Born 1886-95 } & \multicolumn{3}{|c|}{ Born 1876-85 } & \multicolumn{3}{|c|}{ Born 1866-75 } \\
\hline & 1911 & 1921 & 1931 & 1911 & 1921 & 1931 & 1911 & 1921 & 1931 \\
\hline Age & $\begin{array}{c}0.59^{* * *} \\
(0.04)\end{array}$ & $\begin{array}{l}0.08^{*} \\
(0.05)\end{array}$ & $\begin{array}{l}0.038 \\
(0.10)\end{array}$ & $\begin{array}{c}0.06 \\
(0.04)\end{array}$ & $\begin{array}{c}0.07 \\
(0.07)\end{array}$ & $\begin{array}{l}0.27^{*} \\
(0.15)\end{array}$ & $\begin{array}{l}-0.02 \\
(0.08)\end{array}$ & $\begin{array}{l}-0.03 \\
(0.12)\end{array}$ & $\begin{array}{c}0.47 \\
(0.29)\end{array}$ \\
\hline $\operatorname{Age}^{2} \mathrm{x} 10$ & $\begin{array}{c}-0.12 * * * \\
(0.01)\end{array}$ & $\begin{array}{l}-0.01 \\
(0.01) \\
\end{array}$ & $\begin{array}{l}-0.01 \\
(0.01) \\
\end{array}$ & $\begin{array}{l}-0.01 \\
(0.01) \\
\end{array}$ & $\begin{array}{l}-0.01 \\
(0.01) \\
\end{array}$ & $\begin{array}{l}-0.02 \\
(0.03) \\
\end{array}$ & $\begin{array}{l}0.002 \\
(0.01) \\
\end{array}$ & $\begin{array}{l}0.002 \\
(0.01) \\
\end{array}$ & $\begin{array}{l}-0.04^{*} \\
(0.02) \\
\end{array}$ \\
\hline Years since migration & $\begin{array}{c}0.21 * * * \\
(0.02)\end{array}$ & $\begin{array}{c}0.04 * * * \\
(0.01)\end{array}$ & $\begin{array}{c}0.03 * * * \\
(0.01)\end{array}$ & $\begin{array}{c}0.13 * * * \\
(0.01)\end{array}$ & $\begin{array}{c}0.02 * * \\
(0.01) \\
\end{array}$ & $\begin{array}{c}0.01 \\
(0.01) \\
\end{array}$ & $\begin{array}{c}0.11 * * * \\
(0.02)\end{array}$ & $\begin{array}{c}0.02 \\
(-0.02) \\
\end{array}$ & $\begin{array}{c}0.02 \\
(0.02) \\
\end{array}$ \\
\hline Years since migration $^{2}$ x 10 & $\begin{array}{c}-0.21 * * * \\
(0.03) \\
\end{array}$ & $\begin{array}{c}-0.02 * * * \\
(0.01)\end{array}$ & $\begin{array}{l}-0.001 * \\
(0.0031)\end{array}$ & $\begin{array}{c}-0.10 * * * \\
(0.01)\end{array}$ & $\begin{array}{c}-0.01 \\
(0.004) \\
\end{array}$ & $\begin{array}{l}-0.001 \\
(0.003) \\
\end{array}$ & $\begin{array}{c}-0.09 * * * \\
(0.02) \\
\end{array}$ & $\begin{array}{l}-0.01 \\
(0.01) \\
\end{array}$ & $\begin{array}{l}-0.01 \\
(0.01) \\
\end{array}$ \\
\hline No English & $\begin{array}{c}-0.15 * * * \\
(0.02) \\
\end{array}$ & $\begin{array}{c}-0.08 * * * \\
(0.03) \\
\end{array}$ & $\begin{array}{c}-0.23 * * * \\
(0.04) \\
\end{array}$ & $\begin{array}{c}-0.14 * * * \\
(0.02) \\
\end{array}$ & $\begin{array}{c}-0.13 * * * \\
(0.03) \\
\end{array}$ & $\begin{array}{c}-0.25 * * * \\
(0.05) \\
\end{array}$ & $\begin{array}{c}-0.13 * * * \\
(0.03) \\
\end{array}$ & $\begin{array}{c}-0.13 * * * \\
(0.04) \\
\end{array}$ & $\begin{array}{c}-0.38 * * * \\
(0.08) \\
\end{array}$ \\
\hline Free migrants & $\begin{array}{c}-0.46 * * * \\
(0.04) \\
\end{array}$ & $\begin{array}{c}-0.27 * * * \\
(0.04) \\
\end{array}$ & $\begin{array}{c}-0.30 * * * \\
(0.06) \\
\end{array}$ & $\begin{array}{c}-0.40 * * * \\
(0.03) \\
\end{array}$ & $\begin{array}{c}-0.25 * * * \\
(0.05) \\
\end{array}$ & $\begin{array}{l}-0.13 \\
(0.10) \\
\end{array}$ & $\begin{array}{c}-0.41 * * * \\
(0.05) \\
\end{array}$ & $\begin{array}{c}-0.20^{* *} \\
(0.09) \\
\end{array}$ & $\begin{array}{l}-0.17 \\
(0.18) \\
\end{array}$ \\
\hline Preferred migrants & $\begin{array}{c}-0.34 * * * \\
(0.06)\end{array}$ & $\begin{array}{c}-0.43 * * * \\
(0.07)\end{array}$ & $\begin{array}{c}-0.52 * * * \\
(0.07)\end{array}$ & $\begin{array}{c}-0.28 * * * \\
(0.05)\end{array}$ & $\begin{array}{c}-0.24 * * * \\
(0.07)\end{array}$ & $\begin{array}{c}-0.33 * * * \\
(0.11) \\
\end{array}$ & $\begin{array}{c}-0.24 * * * \\
(0.06) \\
\end{array}$ & $\begin{array}{c}-0.29 * * * \\
(0.11)\end{array}$ & $\begin{array}{c}-0.48 * * \\
(0.20)\end{array}$ \\
\hline Non-preferred migrants & $\begin{array}{c}-0.45 * * * \\
(0.05) \\
\end{array}$ & $\begin{array}{c}-0.36 * * * \\
(0.05) \\
\end{array}$ & $\begin{array}{c}-0.61 * * * \\
(0.06) \\
\end{array}$ & $\begin{array}{c}-0.42 * * * \\
(0.04) \\
\end{array}$ & $\begin{array}{c}-0.31 * * * \\
(0.06) \\
\end{array}$ & $\begin{array}{c}-0.43 * * * \\
(0.10) \\
\end{array}$ & $\begin{array}{c}-0.40 * * * \\
(0.05) \\
\end{array}$ & $\begin{array}{c}-0.38 * * * \\
(0.10) \\
\end{array}$ & $\begin{array}{c}-0.58 * * * \\
(0.19) \\
\end{array}$ \\
\hline $\mathrm{R}^{2}$ & 0.22 & 0.14 & 0.31 & 0.19 & 0.19 & 0.28 & 0.23 & 0.19 & 0.24 \\
\hline $\mathrm{N}$ & 10470 & 10178 & 7889 & 10996 & 8272 & 5697 & 6153 & 4616 & 2557 \\
\hline
\end{tabular}

Notes: Canadian Census samples of 1911, 1921, and 1931 - see text for further details. Estimation is by OLS. Coefficients on age squared and ysm squared are scaled up by a factor of 10. Weighted with census sampling weights. Estimates also include dummy variable controls for occupation and Province of residence and a constant term. A full list of coefficients is available in the Appendix Table A5. Heteroskedasticyrobust standard errors in parentheses. $* * *, * *$ and $*$ indicate coefficients significant at $1 \%, 5 \%$, and $10 \%$ level. 
Table 5: Regression results, weekly earnings

\begin{tabular}{|c|c|c|c|c|c|c|c|c|c|}
\hline & \multicolumn{3}{|c|}{ Born 1886-95 } & \multicolumn{3}{|c|}{ Born 1876-85 } & \multicolumn{3}{|c|}{ Born 1866-75 } \\
\hline & 1911 & 1921 & 1931 & 1911 & 1921 & 1931 & 1911 & 1921 & 1931 \\
\hline Age & $\begin{array}{c}0.49^{* * *} \\
(0.03)\end{array}$ & $\begin{array}{l}0.13^{* *} \\
(0.05)\end{array}$ & $\begin{array}{c}0.05 \\
(0.07)\end{array}$ & $\begin{array}{c}0.08^{* *} \\
(0.04)\end{array}$ & $\begin{array}{c}0.08 \\
(0.07)\end{array}$ & $\begin{array}{l}0.22 * * \\
(0.11)\end{array}$ & $\begin{array}{c}0.05 \\
(0.08)\end{array}$ & $\begin{array}{l}-0.02 \\
(0.15)\end{array}$ & $\begin{array}{c}0.15 \\
(0.21)\end{array}$ \\
\hline $\operatorname{Age}^{2} \times 10$ & $\begin{array}{c}-0.10 * * * \\
(0.01)\end{array}$ & $\begin{array}{c}-0.02 * * \\
(0.01)\end{array}$ & $\begin{array}{l}-0.01 \\
(0.01) \\
\end{array}$ & $\begin{array}{l}-0.01 * \\
(0.01) \\
\end{array}$ & $\begin{array}{l}-0.01 \\
(0.01) \\
\end{array}$ & $\begin{array}{c}-0.02 * * \\
(0.01)\end{array}$ & $\begin{array}{l}-0.01 \\
(0.01) \\
\end{array}$ & $\begin{array}{l}0.002 \\
(0.02) \\
\end{array}$ & $\begin{array}{l}-0.01 \\
(0.02) \\
\end{array}$ \\
\hline Years since migration & $\begin{array}{l}-0.01 \\
(0.02) \\
\end{array}$ & $\begin{array}{c}0.04 * * * \\
(0.01)\end{array}$ & $\begin{array}{c}0.02 * * * \\
(0.01)\end{array}$ & $\begin{array}{c}0.01 \\
(0.01) \\
\end{array}$ & $\begin{array}{c}0.01 \\
(0.01) \\
\end{array}$ & $\begin{array}{c}-0.02 * * \\
(0.01)\end{array}$ & $\begin{array}{l}0.004 \\
(0.02) \\
\end{array}$ & $\begin{array}{c}0.02 \\
(0.02) \\
\end{array}$ & $\begin{array}{c}0.02 \\
(0.02) \\
\end{array}$ \\
\hline Years since migration $^{2} \times 10$ & $\begin{array}{c}0.00 \\
(0.02) \\
\end{array}$ & $\begin{array}{c}-0.02 * * * \\
(0.01)\end{array}$ & $\begin{array}{l}-0.003 \\
(0.002) \\
\end{array}$ & $\begin{array}{l}-0.003 \\
(0.01) \\
\end{array}$ & $\begin{array}{l}-0.003 \\
(0.004) \\
\end{array}$ & $\begin{array}{c}0.01 * * * \\
(0.002) \\
\end{array}$ & $\begin{array}{l}0.002 \\
(0.02) \\
\end{array}$ & $\begin{array}{l}-0.003 \\
(0.01) \\
\end{array}$ & $\begin{array}{l}-0.002 \\
(0.004) \\
\end{array}$ \\
\hline No English & $\begin{array}{c}-0.13 * * * \\
(0.02) \\
\end{array}$ & $\begin{array}{c}-0.16^{* * *} \\
(0.03) \\
\end{array}$ & $\begin{array}{c}-0.37 * * * \\
(0.03) \\
\end{array}$ & $\begin{array}{c}-0.19 * * * \\
(0.02) \\
\end{array}$ & $\begin{array}{c}-0.19 * * * \\
(0.03) \\
\end{array}$ & $\begin{array}{c}-0.42 * * * \\
(0.03) \\
\end{array}$ & $\begin{array}{c}-0.17 * * * \\
(0.02) \\
\end{array}$ & $\begin{array}{c}-0.11 * * * \\
(0.04) \\
\end{array}$ & $\begin{array}{c}-0.45^{* * *} * \\
(0.05) \\
\end{array}$ \\
\hline Free migrants & $\begin{array}{l}-0.01 \\
(0.03) \\
\end{array}$ & $\begin{array}{c}-0.24 * * * \\
(0.04) \\
\end{array}$ & $\begin{array}{c}-0.24 * * * \\
(0.04) \\
\end{array}$ & $\begin{array}{c}-0.11 * * * \\
(0.02)\end{array}$ & $\begin{array}{c}-0.18 * * * \\
(0.05) \\
\end{array}$ & $\begin{array}{c}0.02 \\
(0.07) \\
\end{array}$ & $\begin{array}{c}-0.19 * * * \\
(0.04)\end{array}$ & $\begin{array}{c}-0.23 * * \\
(0.09) \\
\end{array}$ & $\begin{array}{c}-0.34 * * \\
(0.14) \\
\end{array}$ \\
\hline Preferred migrants & $\begin{array}{c}0.06 \\
(0.05) \\
\end{array}$ & $\begin{array}{c}-0.46^{* * *} \\
(0.08)\end{array}$ & $\begin{array}{c}-0.41 * * * \\
(0.06) \\
\end{array}$ & $\begin{array}{l}-0.03 \\
(0.04) \\
\end{array}$ & $\begin{array}{c}-0.22 * * * \\
(0.07)\end{array}$ & $\begin{array}{l}-0.10 \\
(0.08) \\
\end{array}$ & $\begin{array}{c}-0.14 * * * \\
(0.05)\end{array}$ & $\begin{array}{c}-0.29 * * * \\
(0.11)\end{array}$ & $\begin{array}{c}-0.51 * * * \\
(0.15)\end{array}$ \\
\hline Non-preferred migrants & $\begin{array}{c}0.02 \\
(0.03) \\
\end{array}$ & $\begin{array}{c}-0.38 * * * \\
(0.05)\end{array}$ & $\begin{array}{c}-0.55 * * * \\
(0.04) \\
\end{array}$ & $\begin{array}{c}-0.22 * * * \\
(0.038)\end{array}$ & $\begin{array}{c}-0.31 * * * \\
(0.05) \\
\end{array}$ & $\begin{array}{c}-0.34 * * * \\
(0.07)\end{array}$ & $\begin{array}{c}-0.30 * * * \\
(0.04) \\
\end{array}$ & $\begin{array}{c}-0.39 * * * \\
(0.10) \\
\end{array}$ & $\begin{array}{c}-0.65 * * * \\
(0.13) \\
\end{array}$ \\
\hline $\mathrm{R}^{2}$ & 0.19 & 0.04 & 0.071 & 0.053 & 0.03 & 0.06 & 0.05 & 0.03 & 0.06 \\
\hline $\mathrm{N}$ & 10436 & 6454 & 9606 & 10879 & 5347 & 6968 & 6043 & 2930 & 3140 \\
\hline
\end{tabular}

Notes: Canadian Census samples of 1911, 1921, and 1931 - see text for further details. Estimation is by OLS. Coefficients on age squared and ysm squared are scaled up by a factor of 10. Weighted with census sampling weights. Estimates also include dummy variable controls for Province of residence and a constant term. A full list of coefficients is available in the Appendix Table A6. Heteroskedasticy-robust standard errors in parentheses. $* * *, * *$ and $*$ indicate coefficients significant at $1 \%, 5 \%$, and $10 \%$ level. 
Table 6: Regression results, weekly earnings, occupation controls

\begin{tabular}{|c|c|c|c|c|c|c|c|c|c|}
\hline & \multicolumn{3}{|c|}{ Born 1886-95 } & \multicolumn{3}{|c|}{ Born $1876-85$} & \multicolumn{3}{|c|}{ Born 1866-75 } \\
\hline & 1911 & 1921 & 1931 & 1911 & 1921 & 1931 & 1911 & 1921 & 1931 \\
\hline Age & $\begin{array}{c}0.49 * * * \\
(0.03)\end{array}$ & $\begin{array}{l}0.09^{*} \\
(0.05)\end{array}$ & $\begin{array}{l}-0.01 \\
(0.07)\end{array}$ & $\begin{array}{c}0.05 \\
(0.04)\end{array}$ & $\begin{array}{c}0.08 \\
(0.07)\end{array}$ & $\begin{array}{c}0.25^{* *} \\
(0.11)\end{array}$ & $\begin{array}{c}0.02 \\
(0.07)\end{array}$ & $\begin{array}{c}0.10 \\
(0.15)\end{array}$ & $\begin{array}{c}0.28 \\
(0.22)\end{array}$ \\
\hline $\operatorname{Age}^{2} \times 10$ & $\begin{array}{c}-0.10 * * * \\
(0.010)\end{array}$ & $\begin{array}{l}-0.01 \\
(0.01) \\
\end{array}$ & $\begin{array}{l}0.001 \\
(0.01) \\
\end{array}$ & $\begin{array}{l}-0.008 \\
(0.006) \\
\end{array}$ & $\begin{array}{l}-0.01 \\
(0.01) \\
\end{array}$ & $\begin{array}{c}-0.03 * * \\
(0.01)\end{array}$ & $\begin{array}{l}-0.003 \\
(0.01) \\
\end{array}$ & $\begin{array}{l}-0.01 \\
(0.01) \\
\end{array}$ & $\begin{array}{l}-0.03 \\
(0.02) \\
\end{array}$ \\
\hline Years since migration & $\begin{array}{l}-0.002 \\
(0.02) \\
\end{array}$ & $\begin{array}{c}0.04 * * * \\
(0.01) \\
\end{array}$ & $\begin{array}{c}0.02 * * * \\
(0.01) \\
\end{array}$ & $\begin{array}{c}0.007 \\
(0.010) \\
\end{array}$ & $\begin{array}{c}0.02 * * \\
(0.01) \\
\end{array}$ & $\begin{array}{l}-0.01 \\
(0.01) \\
\end{array}$ & $\begin{array}{l}0.004 \\
(0.02) \\
\end{array}$ & $\begin{array}{r}0.02 \\
(0.02) \\
\end{array}$ & $\begin{array}{c}0.01 \\
(0.02) \\
\end{array}$ \\
\hline Years since migration $^{2} \times 10$ & $\begin{array}{c}-0.01 \\
(0.002) \\
\end{array}$ & $\begin{array}{c}-0.01 * * * \\
(0.01) \\
\end{array}$ & $\begin{array}{c}-0.004 * \\
(0.002) \\
\end{array}$ & $\begin{array}{l}-0.005 \\
(0.011) \\
\end{array}$ & $\begin{array}{c}-0.01 \\
(0.004) \\
\end{array}$ & $\begin{array}{c}0.003 \\
(0.002) \\
\end{array}$ & $\begin{array}{l}-0.003 \\
(0.02) \\
\end{array}$ & $\begin{array}{l}-0.004 \\
(0.01) \\
\end{array}$ & $\begin{array}{r}-0.003 \\
(0.01) \\
\end{array}$ \\
\hline No English & $\begin{array}{c}-0.119 * * * \\
(0.02) \\
\end{array}$ & $\begin{array}{c}-0.08 * * * \\
(0.03) \\
\end{array}$ & $\begin{array}{c}-0.16 * * * \\
(0.03)\end{array}$ & $\begin{array}{c}-0.123 * * * \\
(0.016) \\
\end{array}$ & $\begin{array}{c}-0.08 * * * \\
(0.03) \\
\end{array}$ & $\begin{array}{c}-0.22 * * * \\
(0.03) \\
\end{array}$ & $\begin{array}{c}-0.08 * * * \\
(0.02) \\
\end{array}$ & $\begin{array}{l}-0.04 \\
(0.04) \\
\end{array}$ & $\begin{array}{c}-0.26 * * * \\
(0.06) \\
\end{array}$ \\
\hline Free migrants & $\begin{array}{l}-0.01 \\
(0.03) \\
\end{array}$ & $\begin{array}{c}-0.20 * * * \\
(0.04)\end{array}$ & $\begin{array}{c}-0.17 * * * \\
(0.04)\end{array}$ & $\begin{array}{c}-0.067 * * * \\
(0.024) \\
\end{array}$ & $\begin{array}{c}-0.18 * * * \\
(0.05)\end{array}$ & $\begin{array}{l}-0.01 \\
(0.06) \\
\end{array}$ & $\begin{array}{c}-0.11 * * * \\
(0.03)\end{array}$ & $\begin{array}{c}-0.18 * * \\
(0.09) \\
\end{array}$ & $\begin{array}{l}-0.22 \\
(0.14) \\
\end{array}$ \\
\hline Preferred migrants & $\begin{array}{c}0.06 \\
(0.05) \\
\end{array}$ & $\begin{array}{c}-0.37 * * * \\
(0.08)\end{array}$ & $\begin{array}{c}-0.25 * * * \\
(0.05)\end{array}$ & $\begin{array}{l}0.071^{*} \\
(0.039) \\
\end{array}$ & $\begin{array}{c}-0.16 * * \\
(0.06)\end{array}$ & $\begin{array}{l}-0.05 \\
(0.07) \\
\end{array}$ & $\begin{array}{c}0.01 \\
(0.04) \\
\end{array}$ & $\begin{array}{l}-0.19^{*} \\
(0.11) \\
\end{array}$ & $\begin{array}{c}-0.37 * * \\
(0.15)\end{array}$ \\
\hline Non-preferred migrants & $\begin{array}{c}0.04 \\
(0.03) \\
\end{array}$ & $\begin{array}{c}-0.23 * * * \\
(0.05)\end{array}$ & $\begin{array}{c}-0.33 * * * \\
(0.04)\end{array}$ & $\begin{array}{c}-0.093 * * * \\
(0.028) \\
\end{array}$ & $\begin{array}{c}-0.18 * * * \\
(0.05)\end{array}$ & $\begin{array}{c}-0.16 * * \\
(0.06) \\
\end{array}$ & $\begin{array}{c}-0.12 * * * \\
(0.04) \\
\end{array}$ & $\begin{array}{c}-0.25 * * \\
(0.10) \\
\end{array}$ & $\begin{array}{c}-0.42 * * * \\
(0.14)\end{array}$ \\
\hline $\mathrm{R}^{2}$ & 0.22 & 0.13 & 0.26 & 0.15 & 0.16 & 0.25 & 0.21 & 0.14 & 0.20 \\
\hline $\mathrm{N}$ & 10105 & 6104 & 7871 & 10547 & 5052 & 5685 & 5857 & 2759 & 2549 \\
\hline
\end{tabular}

Notes: Canadian Census samples of 1911, 1921, and 1931 - see text for further details. Estimation is by OLS. Coefficients on age squared and ysm squared are scaled up by a factor of 10 . Weighted with census sampling weights. Estimates also include dummy variable controls for

Province of residence and a constant term. A full list of coefficients is available in the Appendix Table A7. Heteroskedasticy-robust standard errors in parentheses. $\quad * * *, * *$ and $*$ indicate coefficients significant at $1 \%, 5 \%$, and $10 \%$ level. 
Table 7: Ethnic concentration and immigrant earnings, 1921 and 1931

\begin{tabular}{|c|c|c|c|c|c|c|}
\hline & \multicolumn{2}{|c|}{ Born 1886-95 } & \multicolumn{2}{|c|}{ Born 1876-85 } & \multicolumn{2}{|c|}{ Born 1866-75 } \\
\hline & 1921 & 1931 & 1921 & 1931 & 1921 & 1931 \\
\hline Free migrants & $\begin{array}{c}-0.30 * * * \\
(0.05)\end{array}$ & $\begin{array}{c}-0.32 * * * \\
(0.06)\end{array}$ & $\begin{array}{c}-0.33 * * * \\
(0.06)\end{array}$ & $\begin{array}{l}-0.17^{*} \\
(0.10)\end{array}$ & $\begin{array}{c}-0.20 * * \\
(0.10)\end{array}$ & $\begin{array}{l}-0.18 \\
(0.18)\end{array}$ \\
\hline Preferred migrants & $\begin{array}{c}-0.64 * * * \\
(0.11) \\
\end{array}$ & $\begin{array}{c}-0.48 * * * \\
(0.08) \\
\end{array}$ & $\begin{array}{c}-0.40 * * * \\
(0.11) \\
\end{array}$ & $\begin{array}{c}-0.35 * * * \\
(0.12) \\
\end{array}$ & $\begin{array}{c}-0.33 * * * \\
(0.12) \\
\end{array}$ & $\begin{array}{c}-0.50 * * \\
(0.20) \\
\end{array}$ \\
\hline Non-preferred migrants & $\begin{array}{c}-0.41 * * * \\
(0.06)\end{array}$ & $\begin{array}{c}-0.61 * * * \\
(0.07)\end{array}$ & $\begin{array}{c}-0.48 * * * \\
(0.07)\end{array}$ & $\begin{array}{c}-0.42 * * \\
(0.11)\end{array}$ & $\begin{array}{c}-0.41 * * * \\
(0.12)\end{array}$ & $\begin{array}{c}-0.50 * * * \\
(0.20)\end{array}$ \\
\hline Own ethnic concentration (free) & $\begin{array}{c}2.05 * * \\
(0.87) \\
\end{array}$ & $\begin{array}{l}2.17 * \\
(1.26) \\
\end{array}$ & $\begin{array}{c}3.11 * * * \\
(0.86) \\
\end{array}$ & $\begin{array}{c}5.44 * * * \\
(1.46) \\
\end{array}$ & $\begin{array}{l}3.43 * * \\
(1.60) \\
\end{array}$ & $\begin{array}{c}1.71 \\
(2.53) \\
\end{array}$ \\
\hline Own ethnic concentration $\mathrm{x}$ preferred & $\begin{array}{l}15.9 * \\
(8.93)\end{array}$ & $\begin{array}{c}-10.7 * * \\
(5.18)\end{array}$ & $\begin{array}{c}0.82 \\
(4.21)\end{array}$ & $\begin{array}{l}-4.52 \\
(4.66)\end{array}$ & $\begin{array}{c}1.01 \\
(3.43)\end{array}$ & $\begin{array}{l}-8.69 \\
(7.52)\end{array}$ \\
\hline $\begin{array}{l}\text { Own ethnic concentration } \mathrm{x} \text { non- } \\
\text { preferred }\end{array}$ & $\begin{array}{c}0.07 \\
(2.08) \\
\end{array}$ & $\begin{array}{l}-3.63^{*} \\
(1.97) \\
\end{array}$ & $\begin{array}{c}1.71 \\
(1.82) \\
\end{array}$ & $\begin{array}{c}-8.02 * * * \\
(2.40) \\
\end{array}$ & $\begin{array}{r}1.34 \\
(3.42) \\
\end{array}$ & $\begin{array}{r}-5.67 \\
(4.93) \\
\end{array}$ \\
\hline Standard controls? & $\mathrm{Y}$ & $\mathrm{Y}$ & $\mathrm{Y}$ & $\mathrm{Y}$ & Y & $\mathrm{Y}$ \\
\hline Occupation controls? & $\mathrm{Y}$ & $\mathrm{Y}$ & $\mathrm{Y}$ & $\mathrm{Y}$ & $\mathrm{Y}$ & $\mathrm{Y}$ \\
\hline $\mathrm{R}^{2}$ & 0.16 & 0.31 & 0.207 & 0.285 & 0.210 & 0.250 \\
\hline $\mathrm{N}$ & 6809 & 7651 & 5483 & 5505 & 2971 & 2461 \\
\hline
\end{tabular}

Notes: Canadian Census samples of 1911, 1921, and 1931 - see text for further details. Estimation is by OLS. Heteroskedasticy-robust standard errors in parentheses. $* * *, * *$ and $*$ indicate coefficients significant at $1 \%, 5 \%$, and $10 \%$ level. Standard controls are age and age squared, years since migration and years since migration squared, inability to speak English, and region of residence. Occupation controls are the seven groups used in Tables 4 and 6. 
Figure 1a: Predicted relative immigrant earnings (annual), born 1886, arriving 1911

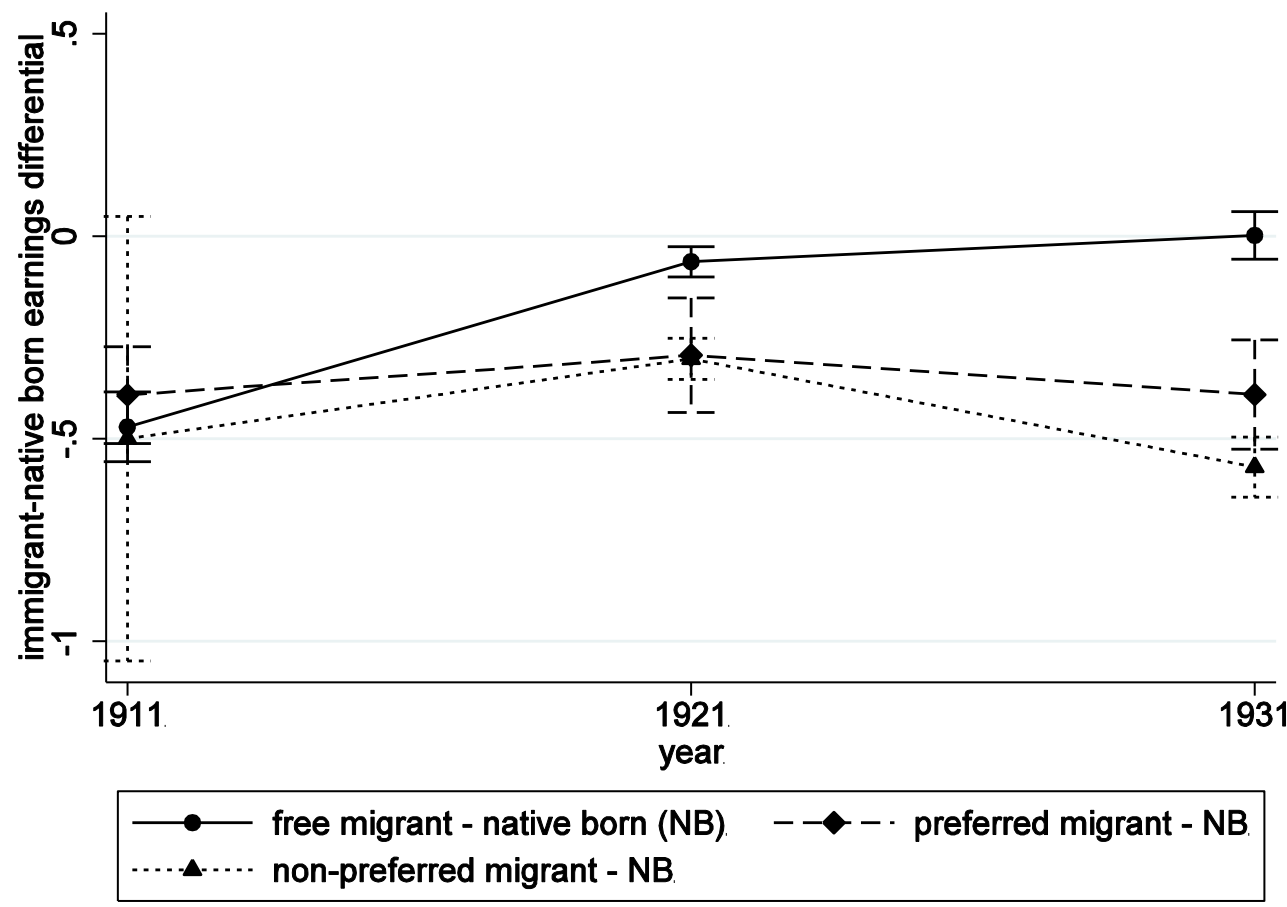

Notes: Derived from regression estimates in Table 2, assuming age of 25 in 1911, ysm of 0 in 1911, speaks English and resides in Ontario.

Figure 1b: Predicted relative immigrant earnings (annual), born 1871, arriving 1896

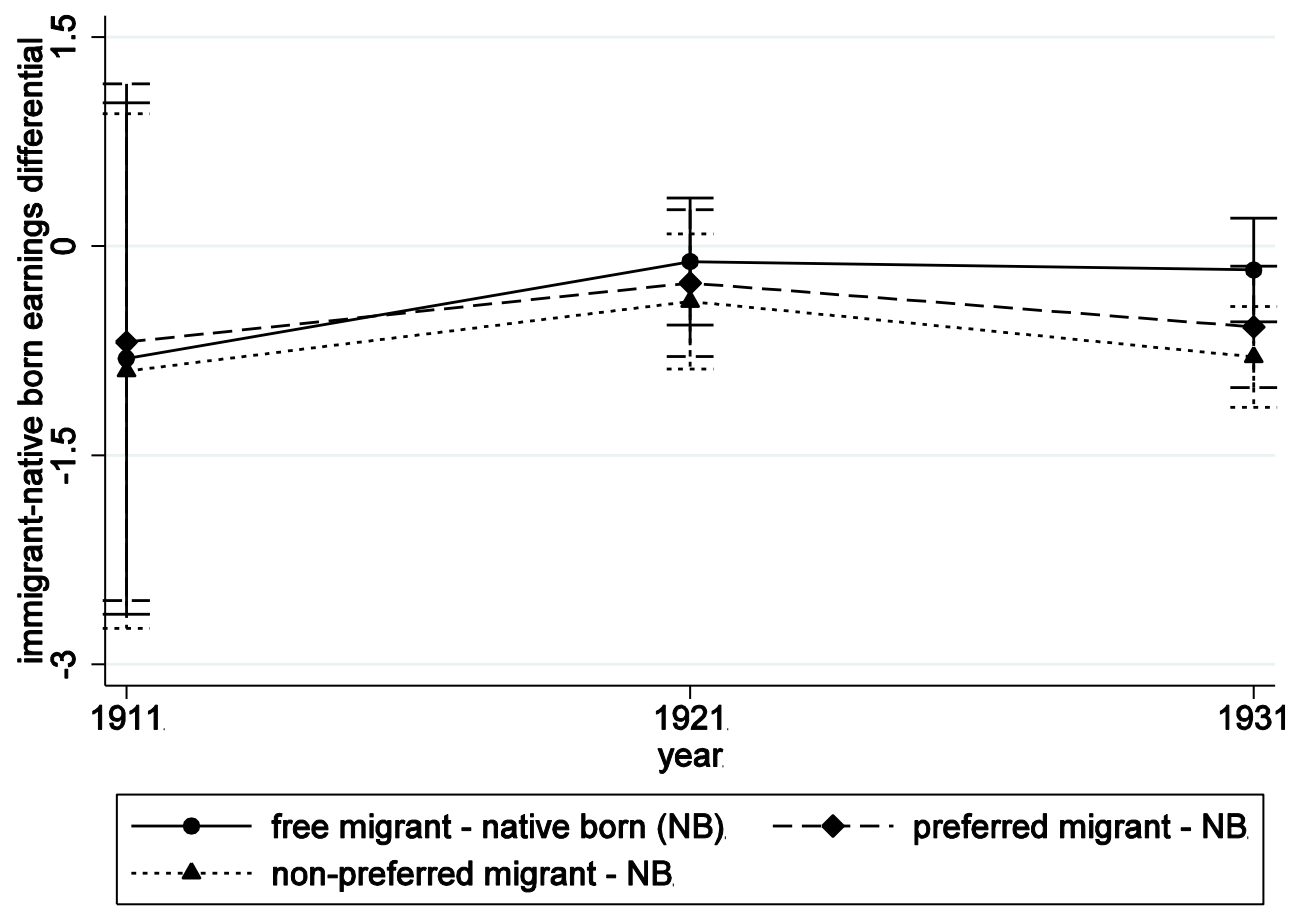

Notes: Derived from regression estimates in Table 2, assuming age of 40 in 1911, ysm of 15 in 1911, speaks English and resides in Ontario. 
Figure 2a: Predicted relative immigrant earnings (annual), born 1886, arriving 1911, with occupation controls

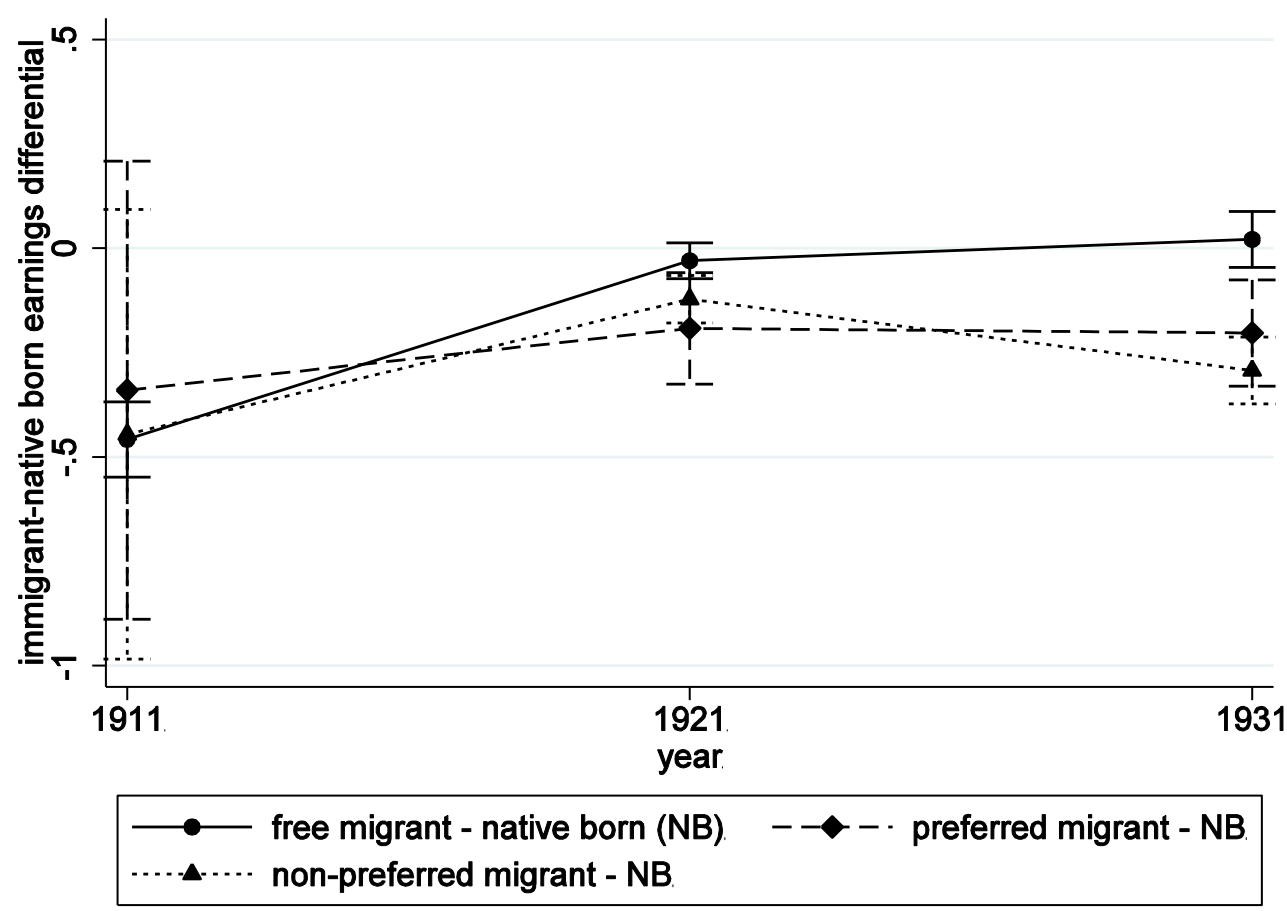

Notes: Derived from regression estimates in Table 3, assuming age of 25 in 1911, ysm of 0 in 1911, employed as operative, speaks English and resides in Ontario.

Figure 2b: Predicted relative immigrant earnings (annual), born 1871, arriving 1896, with occupation controls

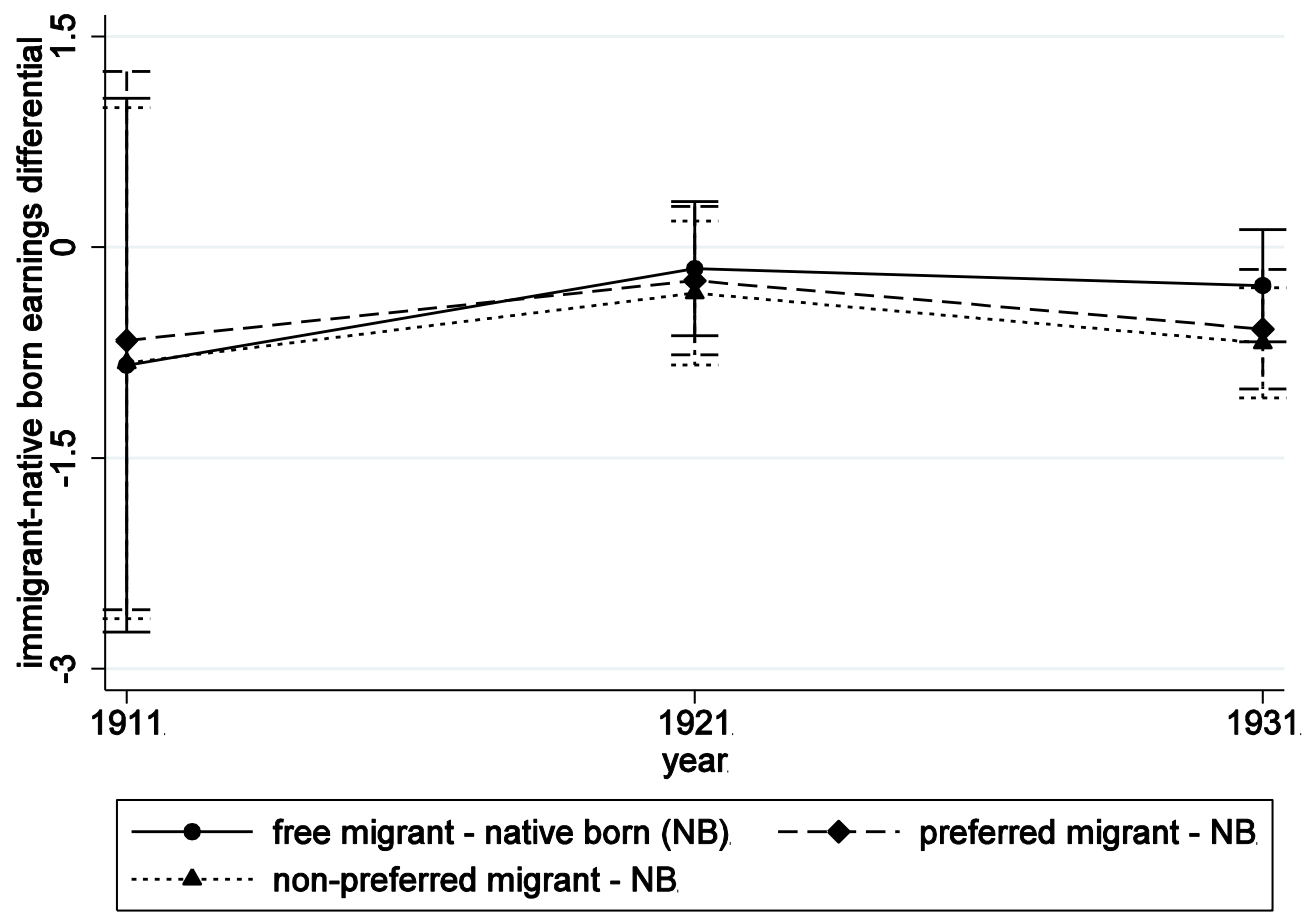

Notes: Derived from regression estimates in Table 3, assuming age of 40 in 1911, ysm of 15 in 1911, employed as operative, speaks English and resides in Ontario. 
Figure 3a: Predicted relative immigrant earnings (weekly), born 1886, arriving 1911, with occupation controls

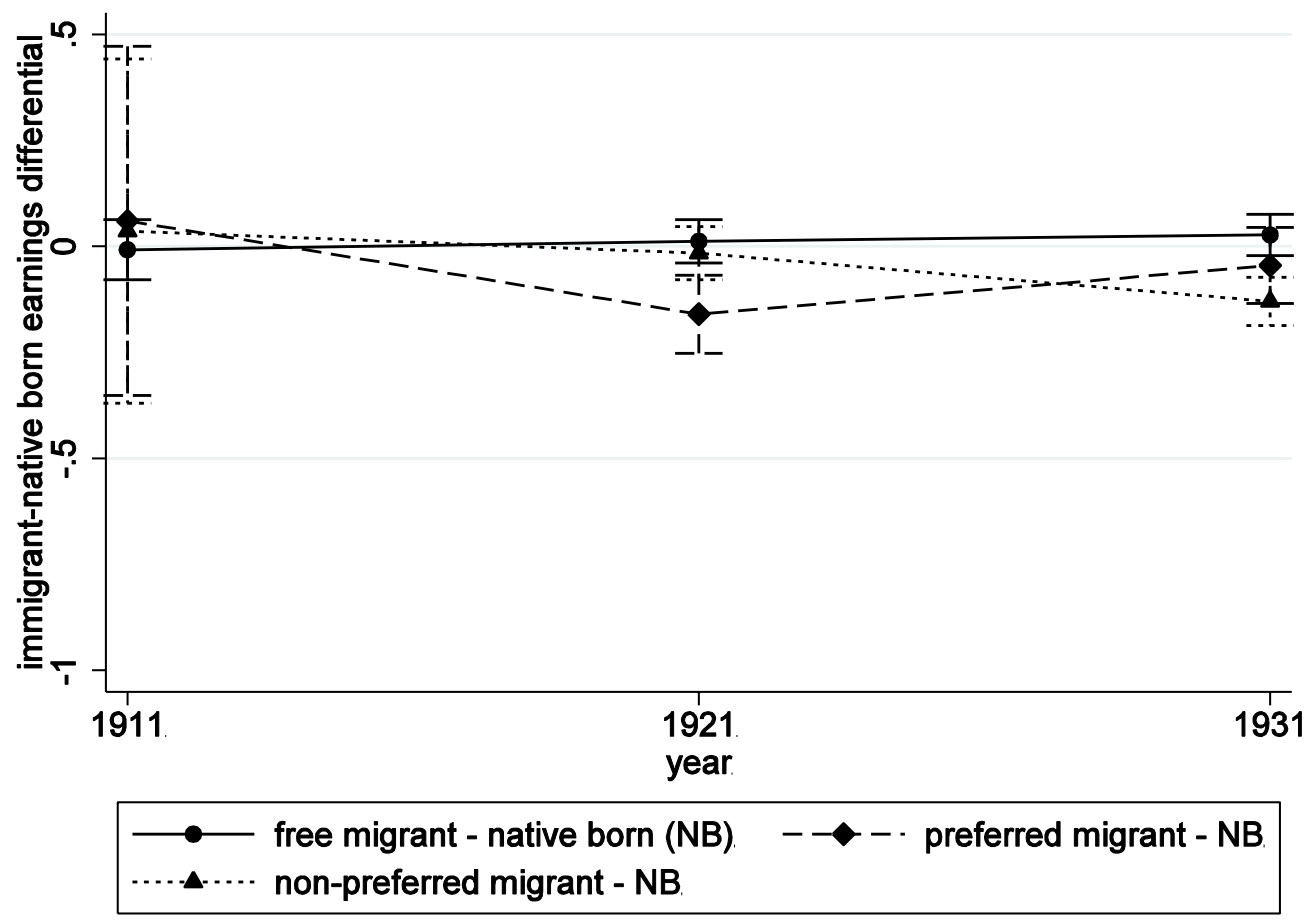

Notes: Derived from regression estimates in Table 5, assuming age of 25 in 1911, ysm of 0 in 1911, employed as operative, speaks English and resides in Ontario.

Figure 3b: Predicted relative immigrant earnings (weekly), born 1871, arriving 1896, with occupation controls

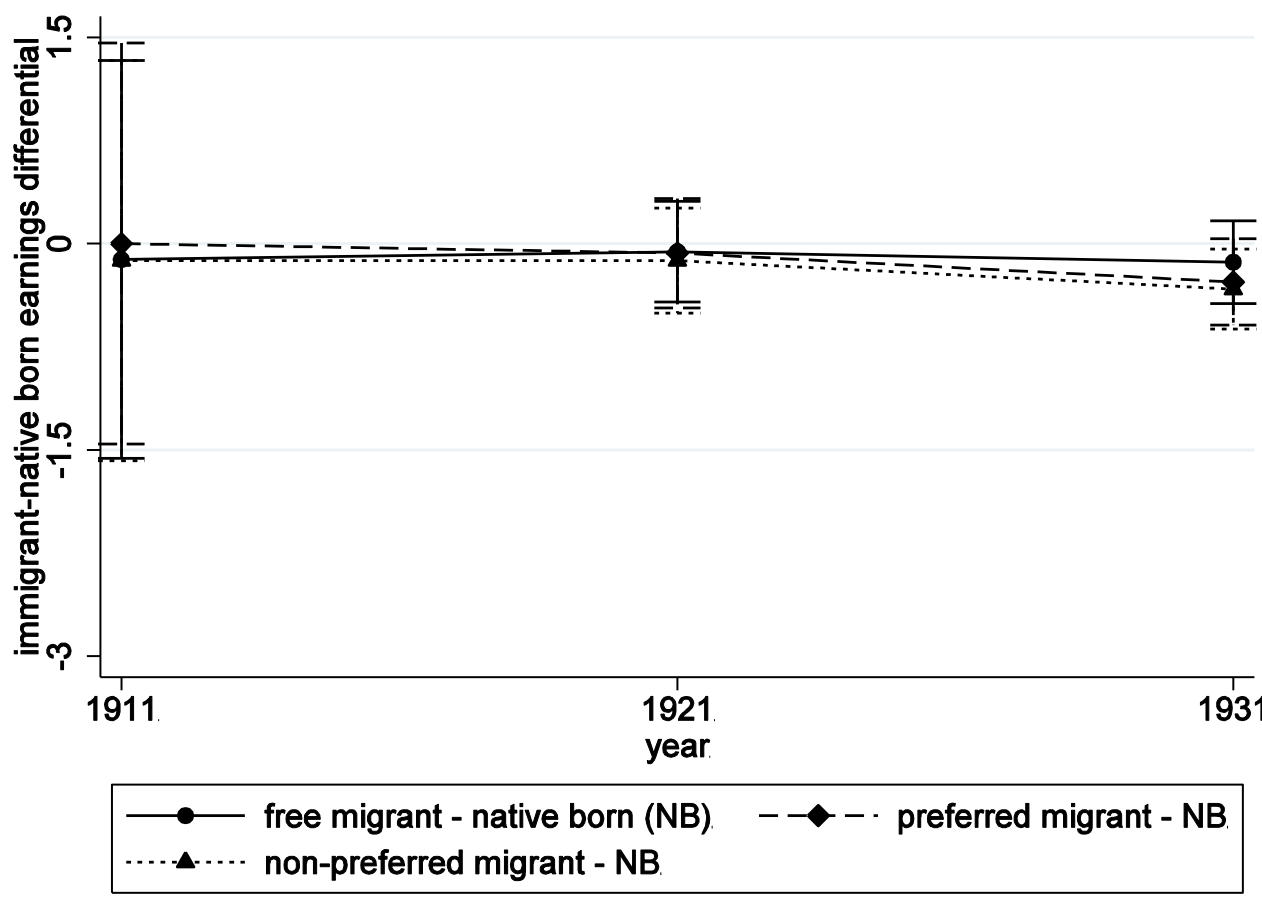

Notes: Derived from regression estimates in Table 5, assuming age of 40 in 1911, ysm of 15 in 1911, employed as operative, speaks English and resides in Ontario. 